\title{
Chapter 7 \\ Ecuadorian Irregular Migrants in Amsterdam and Madrid: The Lived Experience
}

In this chapter the results of the fieldwork realized in Amsterdam and Madrid will be presented. In particular, using the stories and information collected with the methodologies described in Chap. 5, a comparative analysis of the experience of Ecuadorian irregular migrants in the two cities will be discussed.

The objective of the fieldwork was to inquire into the main characteristics of the social experience of Ecuadorian irregular migrants in the two cities. In this respect, the collected material in each context was analysed and looked for possible regularities, behavioural patterns, and common experiences among migrants. Then, these results were comparatively analysed in an attempt to identify differences and similarities.

The analysis of the experience of irregular migrants was divided into two parts. Firstly, the main "legal trajectories" irregular migrants followed in the two contexts were identified. In particular, it was tried to find recurring patterns regarding both the length of the irregular status condition within the migratory trajectories and channels and strategies adopted by migrants to regularize. Secondly, it was tried to figure out what the living conditions of the migrants were when their status was irregular, and what the main related problems and the possible solutions were. The analysis focused on four areas: A. Regularization strategies; B. Work; C. Internal control experience; D. Housing and healthcare. In the conclusion, through a systematic and comparative analysis of the collected information, a general characterization of the irregular migration experience in the two cities was proposed.

Given the great amount of information collected, and its extreme richness, it was necessary to carefully select it. Inevitably, this process implied discarding interesting material and avoiding the discussion of many issues that emerged from the fieldwork. The selection was guided by two principles. On the one hand, it was privileged the material that was closely related to the phenomenon under inquiry. On the other hand, emphasis was put on those issues that could be compared more easily.

Although the qualitative nature of the data that will be presented in this chapter (and the methods used to collect them) were extensively discussed in Chap. 4, here 
it is important to say a word of caution regarding their use. As it will appear, along the chapter, a number of hypotheses, inferences and extrapolations will be presented. It is important to keep in mind that, precisely because of the qualitative nature of the data used to support such propositions, these should not be considered as representative of the whole reality they refer to.

\subsection{Legal Trajectories and Regularization Channels}

In this section the attention will be devoted to the legal trajectories followed by Ecuadorian migrants in the two cities and to the available regularization channels. The concept of "legal trajectories" places the evolution of the migratory experience of migrants in relation to the administrative status allocated to them by the receiving states. The interviewed migrants were asked to recall their migratory stories, taking into consideration the evolution of their legal status and the main legal transitions they had gone through. The goal was to identify recurrent patterns concerning the length of the irregular condition, the channels used to regularize and the relevance of irregularity in their migratory trajectories.

\subsubsection{Legal Trajectories and Regularization Channels in Amsterdam}

Among the 30 Ecuadorian migrants interviewed in the city of Amsterdam, it was possible to identify 4 different legal trajectories (see Fig. 7.1). Two of these (A, B) were largely predominant; the other 2 represented minor, exceptional cases $(C, D)$.

\section{A. Never Regular}

The first legal trajectory concerned the highest number of the interviewed migrants: 15 cases out of a total of 30 . Although having resided, on average, 13 years in Amsterdam, the migrants of this group were not able to find any effective channel to regularize their status. In the majority of cases, they had implemented different strategies on numerous occasions to attain their goal, but their efforts were fruitless. Consequently, their administrative status has been irregular all along their migratory experience.

\section{B. Regularized through marriage or cohabitation agreements}

In numerical terms, this group counted 11 cases out of a total of 30 . This trajectory sharply differs from the previous one; all migrants of this group were able to regularize at some point of their migratory experience. On average, the time needed to get a residence permit was approximately 8 years. The regularization 


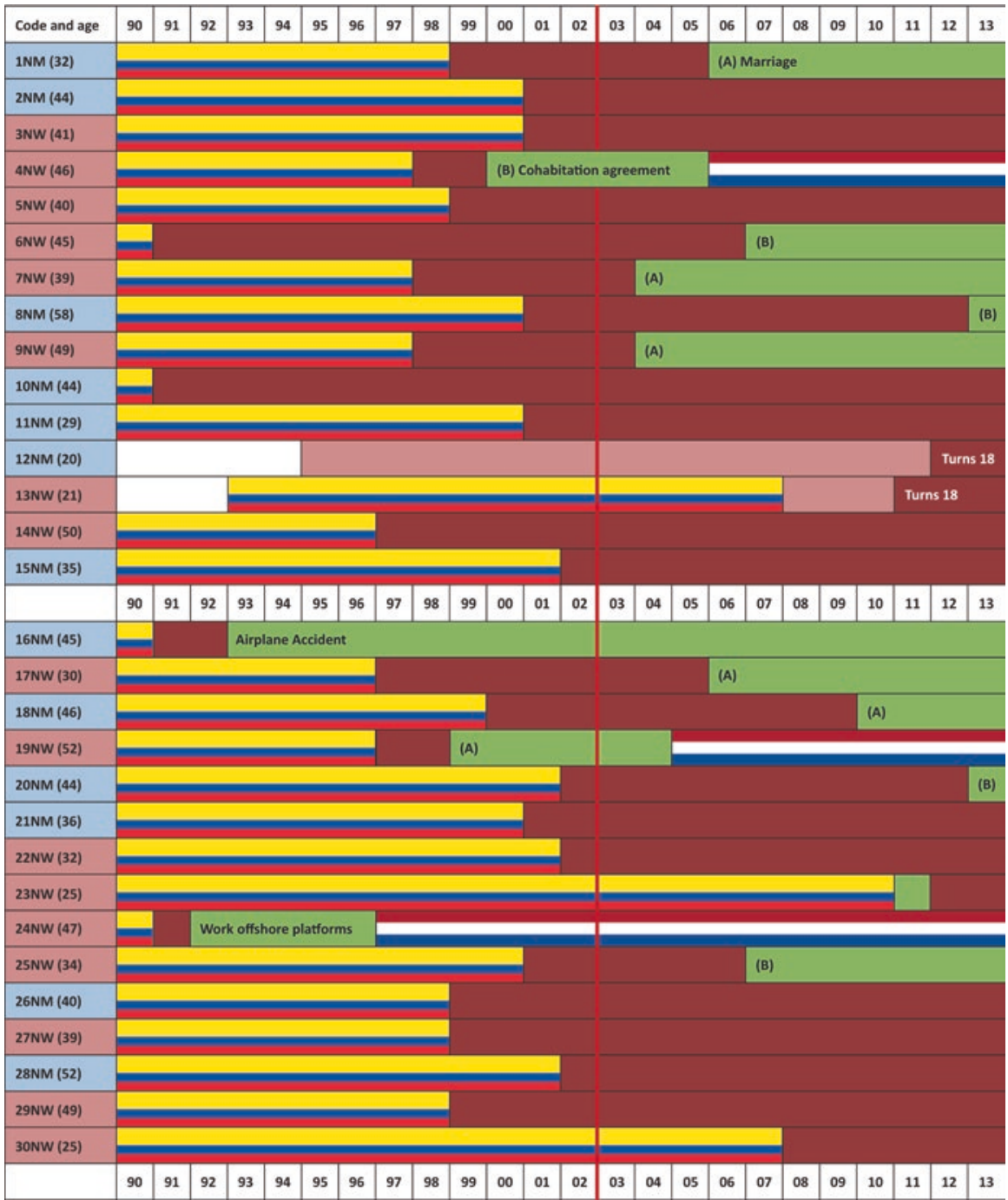

Fig. 7.1 Legal trajectories and regularization channels in Amsterdam (Own data)

Legend: on the left the code and gender of the interviewed (light blue - men, rose - women), in parenthesis the age; in yellow, blue and red bars the years in Ecuador; in red the years with irregular status in Amsterdam; in green the years with regular status in Amsterdam; in red, white and blues bars the years with Dutch citizenship. The red line indicated the introduction of visa request for Ecuadorians

channels used by this group of migrants were marriage (7) or cohabitation agreements (samenwonen) (4). In three cases, the migrants were eventually able to get a Dutch passport. 


\section{Regularized under exceptional circumstances}

One migrant was able to regularize thanks to having legally worked for 8 years. After having overstayed her visa and lived irregularly for one year, in 1992, Marta ${ }^{1}$ $(24 \mathrm{NW})$ was hired by an oil production company to work as a hostess in their offshore platforms in the North Sea. The working contract offered her the possibility to eventually get a permanent residence permit after 8 years.

Another migrant was part of a group of almost 20 Ecuadorian indigenous musicians who obtained a permanent residence permit because they were involved in the "El Al Flight 1862" airplane accident. On 4 October 1992, a cargo aircraft crashed into a residential building in the Bijlmermeer neighbourhood. The great number of irregularly residing migrants involved in the accident, pushed the Dutch authorities to concede a residence permit on a humanitarian basis to all the migrants affected by the accident.

\section{Children of irregular migrants who become of age}

A slightly different trajectory involved two of the interviewed migrants. They were both children of Ecuadorian irregular migrants. One of them was born in the Netherlands. Since their parents did not have a residence permit, also their status was irregular. However, until their 18th birthday, while they did not have a residence permit, they could access public education and their lives were very similar to those of their schoolmates. The day after, they became "fully irregular", in the sense that they had to quit their studies and face all the difficulties connected with the lack of a permit.

\subsubsection{Legal Trajectories and Regularization Channels in Madrid}

Among the 30 Ecuadorian migrants interviewed in the city of Madrid, it was possible to identify 3 different legal trajectories (See Fig. 7.2). The first of these was largely predominant (A), the second represented a minor, yet relevant case (B), and the third was rather exceptional (C) (see Fig. 7.2).

\section{A. Regularized using legal channels}

The migrants who followed the first trajectory were the large majority of the sample; they were 21 out of 30 . The common character of their trajectory was the effective and lasting regularization of their status using the ad-hoc legal channels. On average, the time needed to get a residence permit was 4 years. Regarding the type of channels, there were three available options: A. Extraordinary massive regu-

\footnotetext{
${ }^{1}$ For privacy reasons, all migrants' names that appear in the text are invented. The interviews' translation from Spanish is mine. For age and migratory history of each migrant check Figs. 7.1 and 7.2.
} 


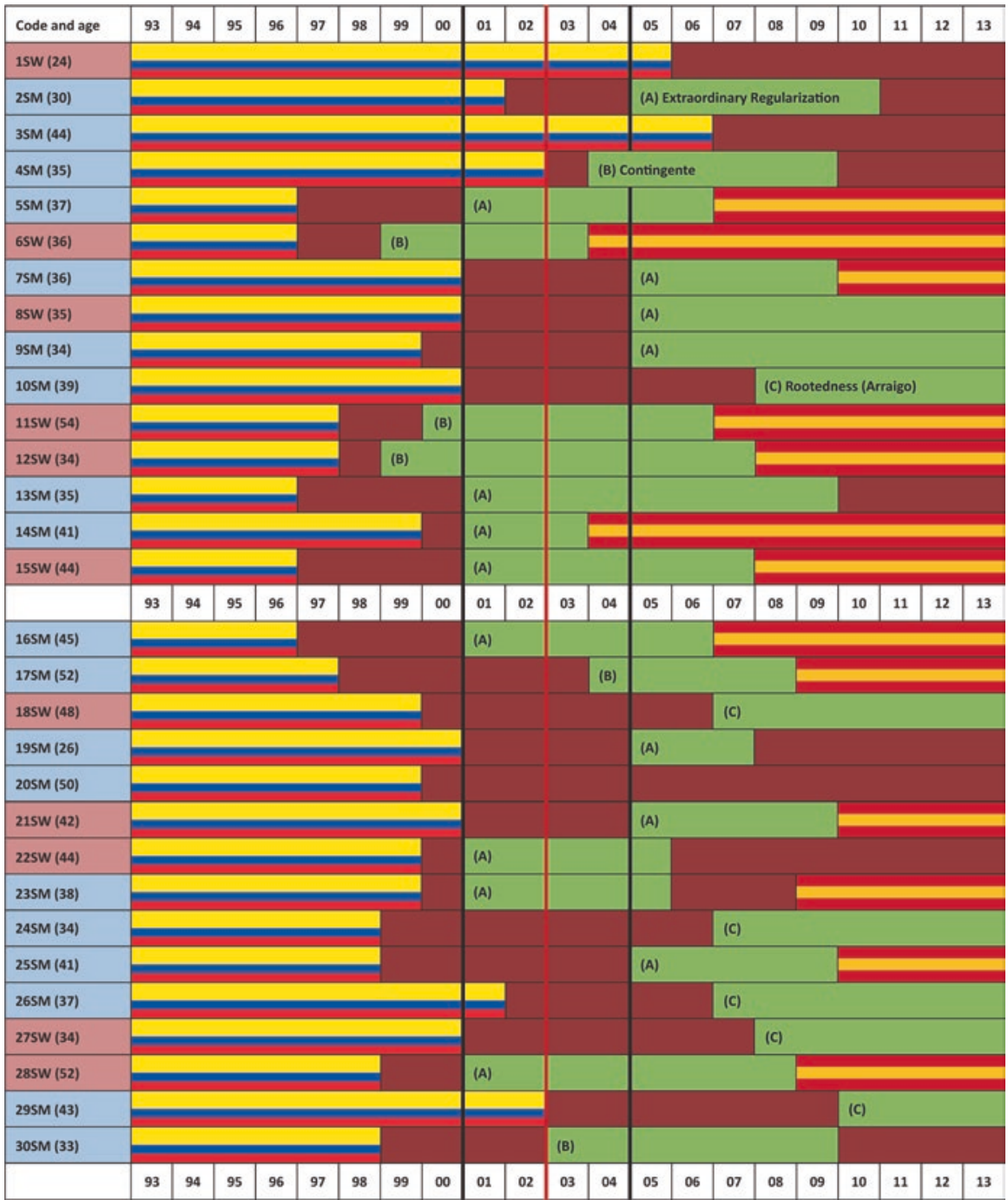

Fig. 7.2 Legal trajectories and regularization channels in Madrid (Own data)

Legend: on the left the code and gender of the interviewed (light blue - men, rose - women), in parenthesis the age; in yellow, blue and red bars the years in Ecuador; in dark red the years with irregular status in Madrid; in green the years with regular status in Madrid; in yellow and red bars the years with Spanish citizenship. The red line indicates the introduction of visa request for Ecuadorians. The black lines the regularization processes of 2000 and 2005

larizations (14 cases); B. Regularization through work quotas (Contigente) (5 cases); C. Regularization through rootedness (Arraigo) (5 cases). 13 migrants within this group obtained Spanish citizenship. 


\section{B. Befallen irregularity}

The second trajectory, which concerned 6 migrants out of 30, was characterized by an initial phase of irregularity, a subsequent regularization through one of the available channels, and, finally, a return to irregularity. In all six cases, the return to the irregular status was determined by the impossibility of the migrants to renew their residence permit. The causes of such impossibility differed. In 4 cases, the migrants committed a crime after their regularization and when they had to renew their permit, they could not fulfil the clean police record requirement (the felonies were: assault on a public officer, driving under the influence (2) and domestic violence). In the other two cases, the migrants could not renew their permit because they did not have the required job offer.

\section{Never regular}

Three interviewed migrants were never able to regularize their administrative status. In one case, the migrant could not fulfil the clean police record requirement when he tried to regularize. In the other two cases, the migrants arrived in Spain after the last extraordinary regularization and they were never able to get a job offer that allowed them to use the arraigo channel.

\subsubsection{Comparison}

As can be observed, the legal trajectories followed by the interviewed Ecuadorian migrants in the cities of Amsterdam and Madrid display a number of significant differences.

Firstly, the number of migrants who were never able to regularize their status sharply differs. In Amsterdam more than one half of the interviewed migrants (17) were never able to regularize their status. In Madrid, in contrast, almost all the interviewed migrants (27) were able to regularize their status at some point.

Secondly, considering the length of the irregular phase within the whole migratory experience of the interviewed migrants, this averaged 12 years in Amsterdam and 5 in Madrid. For those who were able to regularize, the average time needed before getting papers was 8 years in Amsterdam and 4 in Madrid.

Thirdly, regarding the naturalization of former irregular migrants, in Amsterdam this was the case for 3 migrants, while in Madrid for 13 migrants.

Fourthly, excluding the exceptional cases, both in Amsterdam and Madrid, yet in very different proportions, it was possible to identify the never regular and the regularization trajectories. However, in the case of Madrid, a third relevant trajectory, not present in the Amsterdam case, appeared, i.e. the befallen irregularity trajectory.

Fifthly, fundamental differences emerged also in relation to the available regularization channels. In Amsterdam, excluding the two-mentioned exceptional cases, all migrants used the marriage or the cohabitation channels to regularize. It is interesting to point out, that, while these paths are perfectly legal, they were not, at least in 
the Dutch-state intentions, intended as regularization channels. Instead, in Madrid, three, ad-hoc, regularization channels were available. All the interviewed migrants consolidated their administrative status using one of these.

\subsection{Regularization Strategies}

Generally, regularization is not the first priority among migrants. For the vast majority of the interviewed, both in Amsterdam and Madrid, the initial idea when they travelled was to "make money" and go back to their country after a couple of years. The "issue of the papers" was either absent in their minds or openly considered irrelevant.

I didn't know about the papers, I didn't care about the papers... The only thing I wanted was to pay back the money of the loan, to earn enough to build a house in Ecuador and go back...2

A friend of mine told me about the papers... He said: I can help you to get the papers. I said: I do not want the papers, I have my job, I have my money, I will go back soon. What do I want the papers for? $?^{3}$

However, as the complexities of migration were revealed and it became apparent that return was not around the corner, all the migrants, although with different degrees of interest and determination, started to think about finding a way to regularize. Different reasons motivated this change of perspective.

I started to think about the papers and then the visa for Ecuadorians was introduced. I felt as if I was in a cage. I could not travel or go back to Ecuador because, if I left the Netherlands, I was not going to be able to come back. Then, I said to myself: I have to get the papers at all costs! ${ }^{4}$

When I saw that the time in the Netherlands was stretching, I said: I need the papers to bring my children. I expected to go back in two years but after that, I had not yet obtained what I wanted. I could not stay any longer without my children. ${ }^{5}$

I need to get papers because our children are growing up. Now they can go to school, but I heard that when they turn 18, they will not be able to go to school anymore. We don't want that; their education is the most important thing... and they cannot go to Ecuador, they are Dutch, they don't speak Spanish well... I am desperately trying to find a way, but here it is not easy...6

I cannot go back without the papers... If you had children abroad... your children were not born in Ecuador, they were raised here, Sooner or later they will need to go out... If one day

\footnotetext{
${ }^{2}$ Interview with Marco (13SM).

${ }^{3}$ Interview with Elisabeth (4NW).

${ }^{4}$ Interview with Mauricio (18NM).

${ }^{5}$ Interview with Soledad (9NW).

${ }^{6}$ Interview with Lucía (14NW).
} 
I want to go back to Ecuador and the kids want to stay here, I don't want to force them to go. I want to prevent them from having to live what we had to. Going to a country where you do not belong, is tough. If I have a European passport I can go, I know I like Ecuador, it is my country! But if they don't like it, they can come back; they can study for career, you know, with a paper there is a guarantee. ${ }^{?}$

For me the most important limitation of not having papers is that you cannot study, you cannot progress. I don't want to clean houses all my life... It is frustrating to know that you have no future, that your ambitions are blocked there... you want but you can't. Then, for me the priority has always been to get the papers.

Once the papers become a priority, the role of family members, friends or other migrants in providing the information about the options for regularization is fundamental. As a matter of fact, regularization channels, whether designed with that explicit purpose or not, in order to be effective, require a number of steps and fulfilments. Depending on the case, these can be relatively easy to accomplish or extremely difficult.

In this section, the focus will centre on the main strategies developed by migrants to overcome the difficulties in order to regularize their status in Amsterdam and Madrid.

\subsubsection{Regularization Strategies in Amsterdam}

As pointed out by Lucy $(24 \mathrm{NW})$ or Luis $(28 \mathrm{NM})$, in the Netherlands, it is very difficult for a migrant to regularize his/her status.

The papers... that is more than a problem in the Netherlands... that is impossible here... it is very difficult... the only way is to get married, there is no other way. And also that is very hard, because they ask you hundreds of requirements. And now it is not even here, you have to go back and wait in your country. You have to pass an exam of the Dutch language that is very difficult. After all the years I have been here [ 22 years] I have not yet finished learning the language. Then, yes, to get papers is tough. ${ }^{8}$

Here in the Netherlands you can do well... The only thing that you can't get are the papers... that no! It is a question of the state... of the law. They [the Dutch] don't know the word legalization... They did it, but a long time ago... those who benefited were the Muslims... a lot of them. But now they [the Muslim] don't behave well, they want their traditions and are rebelling... So, the Dutch said: No! No more! They stopped there... now the laws are very tough... Not because I have a Dutch passport, can I marry when I want and give papers to whoever I want... The moment I decide to do that I have to fulfil a lot of requirements... ${ }^{9}$

Excluding the exceptional cases, the only effective regularization channel has been through a recognized form of union (marriage or cohabitation agreements)

\footnotetext{
${ }^{7}$ Interview with Patricia $(6 \mathrm{NW})$.

${ }^{8}$ Interview with Lucy (24NW).

${ }^{9}$ Interview with Luis (28NM).
} 
with a Dutch or a European-Union citizen. The two options implied a number of complex procedures and specific requirements. In both cases, the citizenship holder had to earn enough to be able to support the new companion and to have a house with adequate space for two; the migrant had to live in the same house as the companion; both had to be unmarried and the new relationship had to be considered plausible by the authorities.

According to the opinion of many migrants, the option to marry or sign a cohabitation agreement with a Dutch citizen has always been the most difficult one because the requirements were higher and strictly monitored. Moreover, it was necessary to go back to Ecuador and wait there for the approval of the process. Since the end of the 2000s, this option has become even harder because the migrants were required to pass a language exam before getting the residence permit.

The only way to get papers here is doing samenwonen [cohabitation agreement]..., you cohabitate with someone and you get the papers... But if you do it with a Dutch person, they send you to Ecuador to learn the language. No! Now the key to get papers here, the Dutch papers, is to find an Italian, a Spanish person or an Ecuadorian or Colombian who has Dutch papers... I mean, that has a Dutch passport... then you get married... Not married, you do a samenwonen, as if you live together, they examine your case... and ta, ta, ta you show that you live together... you don't need to get married, nothing, and they don't send you to Ecuador... ${ }^{10}$

The best option, then, has always been to marry or sign a cohabitation agreement with a European citizen. The main advantage of this option was that it was not necessary to go back to Ecuador to wait for the visa. Another benefit was that the marriage could be contracted in another country, where the checks on salaries, houses, and veracity of the relationship were not so strict. Three of the interviewed migrants, for instance, travelled illegally to Spain to arrange the marriage there. Once the irregular migrant got the residence permit, it was enough to ask for recognition back in Amsterdam.

\begin{abstract}
It is difficult to find a Dutch citizen willing to arrange a bogus marriage. Those who accept are always in bad conditions... I mean, they are in drugs or have debts or are a bit crazy... Dutch people in their right mind would not do that... They are very serious. Those who can do that are Europeans. A lot of Spaniards, the majority, Italians, French. But the majority are Spaniards. The majority of those who got papers here was because of relationships with Spaniards. Perhaps it is also because of the language or because in Spain there are a lot of Ecuadorians and it is easier to get contacts. Moreover, if you make a deal with a Dutch person, it is much more complicated... You have to go back to Ecuador and that is a loss of time and money. Imagine. You have to go there, it can happen that you stay 2 years, and that means 2 years not working. When you get back, you have lost all your work, you are at zero. In contrast, if you arrange with a European, as long as the bureaucratic process goes on, you can work, you keep producing. ${ }^{11}$
\end{abstract}

For few migrants (2), this type of union arrived as the coronation of a love story; for the majority of the interviewed (9), it was merely a regularization strategy. In this second case, the unions were arranged on the basis of solidarity

\footnotetext{
${ }^{10}$ Interview with José (22NM).

${ }^{11}$ Interview with Maria (4NW).
} 
(usually with friends or family members) (3) or, more often, as part of an economic transaction with the counterpart (6).

The development of a "marriage market" emerged as an adaptive solution to the narrow regularization channels and the high demand for them. On the one hand, the necessity for migrants to regularize at all costs, makes it reasonable for them to "invest" significant amounts of money in order to achieve their goal. On the other hand, for citizenship holders, the option to make some "easy money" without much risk could be attractive.

Considering all costs, until now, I have spent almost 10,000 euro. Only to the girl I had to pay 8,000 euro, the rest has been for the lawyers... Yet, I am happy now, I think it was a good investment. ${ }^{12}$

It is not easy but you find someone. There are many girls and kids available. They used to charge you 5,000 but now it is 8,000, 9,000 euro. Right now for less than 9,000 you don't find Dutch papers. If you have Dutch papers and you want to sell them to a girl, you know you have 10,000 euro... ${ }^{13}$

Yet, such transactions did not necessarily guarantee a good result. In many cases, the requirements were not met or the authorities suspected the veracity of the union. In those cases, new documents could be asked for or the permits could be simply denied. For the migrants, this could mean the beginning of a painful and costly Via Crucis of appeals and rejections that usually did not help them very much. Of course, once the deal was closed and the money paid, the outcome of the process was not a business of the vendor; for the migrants it was therefore impossible to get the money back or to retaliate somehow. In this type of transaction, the condition of legal weakness of the irregular migrants created the conditions for frauds.

\subsubsection{Regularization Strategies in Madrid}

In Madrid, the availability of a number of effective ad-hoc regularization channels, made it a lot easier for Ecuadorian migrants to normalize their status.

For me it was very easy to regularize. After some three months working for a construction company, my boss said to me: do you want papers? I said: yes! I went to ask what I had to do at the foreign office. They said that what was needed was the registration to the municipal record and work contract and that my boss went there. I had already enrolled in the municipal register, because, everyone told you to register the day after arriving in Spain. So my boss went with the contract and everything was arranged. I had to go to Ecuador to pick up the visa, that was the only problem. But everything went well and after three months I already had my residence permit. ${ }^{14}$

\footnotetext{
${ }^{12}$ Interview with Manuel (20NM).

${ }^{13}$ Interview with José (22NM).

${ }^{14}$ Interview with Juan (4SM).
} 
With the extraordinary regularizations, it was super easy to get papers. You did not even need to go back to Ecuador. All you needed was the municipal record and a job... The only problem was to get the criminal record from Ecuador... I thought it was not going to arrive in time, my sister helped me in Quito... ${ }^{15}$

The three fundamental requirements, common to all the three previously mentioned legal schemes, were: the possession of a job offer, the presence in Spain before a certain date and the holding of a clean criminal record.

While these requirements were generally easy to fulfil, something that explains the high degree of regularization success, a number of strategies were developed in order to overcome possible problems. The requirement of a job offer in order to regularize and of a valid working contract in order to renew the residence permit, could be tricked with the use of false job offers or fake work contracts. In the latter case, the migrant would pay the social security and the contract costs to the employer so that he or she could pay them as if the migrant was effectively working. This type of strategy became particularly useful after the beginning of the economic crisis. The high levels of unemployment among migrants and the reduction of jobs more in general made it more difficult for migrants to satisfy the requests related to work. This affected both the regular migrants who had to renew their residence permit but no longer had a job, determining cases of befallen irregularity, and the irregular migrants who wanted to regularize using the rootedness channel (arraigo).

A distinction must be made regarding the criminal record issue. One of the main requirements needed to regularize through the extraordinary regularization processes was to present a document that certified that the migrant had not committed crimes in his origin country. If that was not the case, an option was to pay in Ecuador for a falsified criminal record. In the case of the renewal of a residence permit, instead, the requirement was not to have committed criminal offences in Spain. As seen in the situations of the 4 cases of befallen irregularity for criminal precedents, for migrants who could not fulfil this requirement, there was no strategy available.

My residence permit expired three year ago... Everything went well, until the third renewal. I went there with all my documentations, I was relaxed, I didn't expect anything. Then they said that the permit was refused, that I had a problem because I had a criminal record. I was found driving under the influence of substances... I could not believe it... What happened was that once I was driving back home... I had been drinking a few beers with my friends and the Civil Guard stopped me. We are talking about 2 years ago... I had to do the alcohol test and I was above the limit. In that moment, I only had to pay a fine... but they did not tell me that it would affect the papers... but of course these things affect us... At that point I could not do anything. ${ }^{16}$

\footnotetext{
${ }^{15}$ Interview with Lorena (25SW).

${ }^{16}$ Interview with Ricardo (30SM).
} 


\subsubsection{Comparison}

A fundamental difference is observable between the strategies developed in Amsterdam and in Madrid. In Amsterdam, where no ad-hoc channels are available, the majority of migrants who wanted to regularize their status had to find alternative ways. This situation triggered the elaboration of complex and risky strategies. Migrants' efforts focused on exploiting possible legal loopholes or finding ways to (mis-)use channels designed for other aims. The best example of this tendency was the use of marriage and cohabitation agreements as regularization channels. To this end, the strategies ranged from false unions with family members or friends, on a solidarity basis, to bogus unions with strangers, under payment. Another possibility was to travel illegally to countries where union requirements were softer and then to return to Amsterdam. A side effect, then, was the development of an underground business related to the papers and also the proliferations of frauds.

In Madrid, the vast majority of migrants could regularize without much effort thanks to the existing ad-hoc channels. Particular strategies had to be developed only by those who could not fulfil the requirements of those channels. This was, for instance, the case for the migrants without a job offer or a work contract, or for those who had a criminal record. In the first case, the solution was fake contracts, in the second, the falsification of the documentation. However, certainly noteworthy, the adoption of this type of strategies involved just a minority of migrants.

\subsection{Work}

In this section the focus will be on the work experience of Ecuadorian irregular migrants in Amsterdam and Madrid. Given the fact that many migrants were able to regularize, the attention will centre on their experience during the irregular phases of their migration trajectory.

Three main aspects will be analysed: A. the sectors where they were able to find work and the working conditions; B. the working conditions; $\mathrm{C}$. the experience of controls on the worksites and the possible strategies to avoid them.

\subsubsection{Work in Amsterdam}

\section{Sectors}

Regarding the employment sectors of Ecuadorian irregular migrants in Amsterdam, a crucial element emerged from the fieldwork. If until the first years of the 2000s, both men and women had been able to find work in a relatively wide number of sectors, with the passing of time this number drastically fell to practically one sector. 
In 2013, among the 15 migrants who still had an irregular status, 12 worked cleaning private houses, 2 worked in the construction sector and one worked as a domestic help in a private house taking care of children.

During the 1990s and the early 2000s, Ecuadorian irregular migrants were able to find opportunities in numerous sectors. Even though it is not too marked, a certain gender distinction was observable. The interviewed men had been employed in: hotels, cleaning rooms; restaurants, as dishwashers or cooking assistants; the construction sector, mainly as labourers and painters; the cleaning sector, both in offices and private houses; the port, as loaders; on the streets, playing musical instruments and selling handcraft products. Women had been employed in: hotels, cleaning rooms; restaurants, as dishwashers or cooking assistants; the cleaning sector, both in offices and private houses; as domestic help in private houses; on the streets, selling handcraft products. In many cases, the migrants had more than one job. A recurrent practice, especially among those who had a job with shifts, for instance, in restaurants or hotels, was to supplement their income by going to clean private houses in their free time.

From the early 2000s, the employment opportunities for irregular migrants started to fall. In many sectors, it became increasingly difficult to find work. Employers were no longer eager to employ migrants with an irregular status. For those migrants who had been working for a long time with the same employer, it was easier to keep their occupation. For those who had been fired and had to find a new employment the doors once open were now closed. This phenomenon was particularly evident in the service sector, for instance, in restaurants and hotels, and in the construction sector. By the end of the 2000s, almost no irregular migrant was employed outside the private house cleaning sector.

Asked about their opinion about the reasons for this change, the migrants offered two main explanations. The first was that, from a certain moment onwards, most employers stopped hiring irregular migrants. This was due to the increased fear of possible controls on the work sites and the risk of getting a fine.

The work in the hotel slowly reduced. A lot of people were looking for jobs and the employers preferred to hire those with papers. Maybe in the high season they would still take you on, but only because they really needed workers . The city is full of people, a lot of tourists, so they need you. But now it is difficult because you have to have papers, even during the high season... Additionally, now that it is even harder, you are exploited... As time passes, the situation becomes more demanding, as everything does... Everything has changed... A lot! What can I say? I think that for more than $50 \%$ of us, almost $80 \%, 90 \%$, things have changed. Even in restaurants now they don't hire you if you don't have papers. In hotels the situation is even worse. The market is dead, dead, dead... The only thing possible to survive now, because we still survive [the irregular migrants], is to work in houses... Why? Because they are private... it is private people that want you. There papers are not required, and there nobody stops you... The only thing that can stop you is if you don't have references, but nothing else... ${ }^{17}$

\footnotetext{
${ }^{17}$ Interview with Lucía (14NW).
} 
Now it is not as easy as before. Now nobody wants an illegal employee... In the past years many, many illegal worked here... In hotels, restaurants, in agriculture, picking tomatoes, but now nothing... Now you can only clean... clean, clean and clean... Nothing else. No company wants an illegal migrant... ${ }^{18}$

Now the laws are very strict, nobody will expose himself/herself to hire a person without papers, nobody would risk the controls. ${ }^{19}$

There was a lot of work... there is a lot of work! What happens, though, is that now the government is checking a lot... Before, they hired you "under the table", but now they don't. Now the situation is carefully controlled. Now you have to have papers, you have to have a working permit. So now the possibilities have reduced a lot, a lot! But, the possibility to work "under the table" is still available, for instance working in houses... It is not possible to work in restaurants and hotels anymore... ${ }^{20}$

I had been working in that company for almost two years... We cleaned the windows of the big buildings... One day the inspections were made... I still thank the Lord because that day I was off... But the day after, I went to work, and my boss told me that I had to leave... that he was sorry, but I had to stop coming. ${ }^{21}$

When I arrived here I could work in many places... they did not check... but that time has passed and that situation does not exist anymore... Today there is no employer that hires you if you have no papers. You need to be legal. The employer prefers to have legal workers, it does not matter if you are a migrant worker, but you have to be legal. The fines the employers get are very high... super high. So I stopped searching for jobs in other sectors. It was easier to work cleaning houses. It was also easier work because in the hotel I had to make 40 beds in the house 4 ... I quit in time, thankfully, because many flew to Ecuador because [she means deported] they were caught there working... ${ }^{22}$

Also those who worked in the streets playing musical instruments or selling handicrafts experienced the effects of a changed attitude by the authorities regarding informal work. They were unable to continue their activities without high risks.

We worked playing musical instruments in the squares of the cities... We simply took out our musical instruments and played. We sold our cds and the handicrafts in the street... the police didn't say anything. Now the situation is fucked up! They stop you, they check you, they deport you. We have to run... Before we could travel around Europe, nobody asked us for our passports... Now it is impossible. ${ }^{23}$

The second reason given by the migrants was that new groups of migrants who had papers started to fill the labour market and take the jobs they used to get before.

The first to come were people from the East... they have papers, they started to work where we worked before. Then a lot of migrants from Southern Europe started to come... They go

\footnotetext{
${ }^{18}$ Interview with Roberta (19NW).

${ }^{19}$ Interview with Johanna (27NW).

${ }^{20}$ Interview with Raquel (29NW).

${ }^{21}$ Interview with Lucho (1NM).

${ }^{22}$ Interview with Gabriela (27NW).

${ }^{23}$ Interview with Pablo (16NM).
} 
where the economy is still good. Many Spanish Ecuadorians [Ecuadorians with Spanish nationality] are coming, because they have papers and find work... ${ }^{24}$

Now there are a lot of people coming... people that were in other countries. A lot of people from Spain, because of the situation there... But the situation for work became difficult when the European Union integrated... when those countries, those that are economically bad, where there is no work... So now, here there are more Polish than in Poland... They offer their work, they come to do it... There are Bulgarians... there are people from everywhere... So now, since a lot of people that come to work have papers, for those who are illegal it is more complicated... right now there are plenty of workers with papers. ${ }^{25}$

Yet, the shift towards the cleaning service in private houses was also part of a strategic option of the migrants themselves. Working in private houses offered a number of advantages in terms of salaries, flexibility of hours, security and work necessity.

When the controls started to become tougher, I was scared. I said: no! I won't look for jobs in hotels and restaurants anymore... In houses it is much better... There the people know you, they give you the keys, you go, you respect your schedule... the hours you have to work and you leave... You don't see anybody and it is impossible that they come to check you. Moreover, they pay you more... a lot more. In the hotels and restaurants they used to exploit me. So much, so much! Imagine, in the hotel Arena... They paid me 6 euro, in my houses I don't get less than $10 \ldots$ Can you imagine the difference? ${ }^{26}$

I had always worked in construction, at least for three years... But the problem with construction is that I had to work 10 hours per day, from Monday to Saturday. Of course it was good money... I used to get 600 euro per week, but it was only for short periods. I mean, all those jobs were temporary. It could happen that you stayed 3 or 4 months without a job... Then I got the first job cleaning in a private house. If you were able to find enough houses, it was much better... Much more stable... In construction it was always a problem, I worked for 2 or 3 months and then over... So I said: cleaning is much better, it is more stable and it is not so tough... You work inside... In construction you often have to work outside, in this ice-cold weather [it was February]... ${ }^{27}$

I used to work cleaning offices and cafeterias in the morning... But then I decided to quit and take more houses... Yes, because cleaning houses you earn the same or even more... you have to work less and have free time... ${ }^{28}$

Once we were playing music with a friend in the square... At one point the police arrived and asked for our passports... My friend had papers, so he started to talk to the policeman. He said a lot of things, that we were only musicians, that they should go in search of criminals... He distracted the police... I had the chance to run away... It was the second time in two months that I had to run away... So I talked to my wife, and we decided that it was better that I stopped working in the streets. The best thing was that I went with her to clean houses... ${ }^{29}$

\footnotetext{
${ }^{24}$ Interview with Xavier (23NM).

${ }^{25}$ Interview with Luis (28NM).

${ }^{26}$ Interview with Raquel (29NW).

${ }^{27}$ Interview with Mauricio (8NM).

${ }^{28}$ Interview with Patricia (4NW).

${ }^{29}$ Interview with Javier (23NM).
} 
The advantage of cleaning houses is that it is impossible that they check you. You can go to the houses, clean and that's it. No, no, no... I never had problems, nobody ever has problems in the houses. Nobody has been caught working in a house and kicked out of the country. And many illegal people live even better cleaning houses... Yes, because it is safer... ${ }^{30}$

In that restaurant there were three illegal people working. My brother, a Turkish man and me. It was very hard... they really exploited you. The other workers with papers started to abuse... More work, more work and the same money. And you are not free to get ill, or to have a problem with your family... you have to be there always, 7 solid days there... They don't let you rest... and if you can't work they get angry. 'And you know what: I'll find someone else '. So at one point it was me who decided to quit. I had been helping sometimes my wife with the houses... I didn't like it because I thought it was a ladies' job, cleaning houses, ironing... I had some friends that did that job and earned their unfailing money... Sometimes I made fun of them... hahaha. I laughed... Now that is what I do! I have been doing it for more than five years... And now I have more work than my wife, I don't have enough time to get more houses. With this job I earn 2,000, 2,200 euro per month... ${ }^{31}$

The advantage of working in houses is that it is safer, quieter, easier, healthier... It is more relaxed, and the working hours are more flexible. If you have children, and one morning they wake up ill, you can call and say that you will go the day after... I mean, that possibility to suit your life... That for us who have children is crucial. ${ }^{32}$

\section{Conditions}

Notwithstanding the gradual reduction of sectors and increasing controls, Ecuadorian irregular migrants have generally judged their working conditions and opportunities in Amsterdam as good.

At the beginning it is hard, you don't know anyone... and it is hard. But then you start to know people, to make friends... They talk to you, they help you. Here there is a lot of work... once you start, you find more and more. There is plenty of work. And you can make money. Here the problems are others, the house, the papers, but there is work for everybody. ${ }^{33}$

Working in the hotel, me and my husband, we really made money. We had to work like mules... Maybe, now I think we were a bit exploited... Sometimes my husband started at 6 in the morning and finished at midnight... But we were able to save a lot and buy two houses in Ecuador... ${ }^{34}$

I think that the Netherlands gave us a lot... It has not been easy... you know... Because it is a very different country from ours... the language, the weather... the way the people are here. But we were able to work and send money back... Even though there is an economic crisis, I have a lot of work, sometimes I have to say no... ${ }^{35}$

\footnotetext{
${ }^{30}$ Interview with Gabriela (27NW).

${ }^{31}$ Interview with Pablo (28NM).

${ }^{32}$ Interview with Maria (4NW)

${ }^{33}$ Interview with Jorge (2NM).

${ }^{34}$ Interview with Maria (6NW).

${ }^{35}$ Interview with Pablo (28NW).
} 
Many migrants, both regular and irregular, at the moment of the interview, agreed on the fact that, from the work perspective, the papers, paradoxically, may be a problem.

I think that we who live here without papers live better... Those who have papers are all the time paying for something. Paying, paying, paying... In contrast, we who work under the table, let's say, we 'see' our money... Those who have documents, all their money goes away in payments. If we want to work, I mean, from Monday to Saturday, we can earn a lot more... What happens also is that those who get the papers kind of relax... They don't better themselves... they don't care anymore... It is also because when you are legal, the more you work, the more you pay to the social security. All our friends who have papers are always complaining that they have to pay too much... ${ }^{36}$

When I finally got papers, the state helped me to find a job... It was in a storage centre... The pay was not bad, I don't remember, I think it was 1,200 euro. One day the boss asked me if I wanted to double the hours... I said: yes! I thought, if I earn 1,200 now, next month I would get 2,400 euro. The next month arrived I got 1,800 euro... I said: what?? You know... to work legally is a robbery... But the problem is that when you are legal they check everything... You cannot have more money... They want to know where you got it. For me, it was much better not to have papers... ${ }^{37}$

For a long time we didn't even want the papers. You didn't need them. You had work, the kids could go to school and the people who had been able to get the papers said that they were in a better situation before... Because when they didn't have papers they had money and time, they could do everything... except traveling. With papers you don't have money, you don't have time and you cannot travel, because you don't have money and you don't have time... ${ }^{38}$

Look, when you work here with papers, you get a basic salary that is enough for the basics. If you want to earn more here... you have to have some kind of qualification, you have to speak Dutch... Yet, if you work like us [he means irregularly] the more you work, the more you make. If you work from 8 to 8 , let's say at 10 euro per hour, it is 120 per day... 5, 6, or even 7 days per week. ${ }^{39}$

They say that when you are legal there is the advantage that if you lose your job you have unemployment benefit... But the truth is that if you have that... you are fucked!! They check everything about you. You have to study. You cannot miss a single day without a good reason. If you miss one day you are in troubles. You know, I am a musician. So if I go to work in the streets then I have coins. If you go with the coins to the bank they ask you: where did you get them? Did you work? If you spend a little more they check, if you spend a little less they check... In contrast, when I had my job under the table I could do whatever I wanted... ${ }^{40}$

\footnotetext{
${ }^{36}$ Interview with Luisa (29NW).

${ }^{37}$ Interview with Pablo (16NM).

${ }^{38}$ Interview with Mauricio (18NM).

${ }^{39}$ Interview with Lola $(5 \mathrm{NW})$.

${ }^{40}$ Interview with Pablo (16NM).
} 


\section{Controls and Strategies}

Even if labour controls became increasingly severe through the 2000s, both migrants and employers in Amsterdam have always been alert to the possibility of inspections. For this reason, a number of strategies have been developed both to employ irregular migrants and to escape possible inspections.

Regarding the first aspect, e.g. the irregular employment of migrants, some sectors, for instance, port services, industrial cleaning and construction, appeared to have more inspections and required specific strategies. The decisive factor seemed to be the size of the business. When the employer was a medium-sized or big company, a contract was usually needed. The strategies, therefore, were basically aimed at bypassing this limitation. The two main options were: for migrants to rent or borrow the papers of a regular migrant; for employers, to hire more than one worker with a single contract.

Once I worked in the port. We had to unload and load Russian ships... There you worked with the name of someone who had papers... Every morning when you arrived they told you: if the police of the port come, you have to say that this is your name... And you tired like hell, had to keep repeating to yourself who you were: Juan Charles, Juan Charles, Juan Charles... Sometimes they asked you just to check if you were alert. The "owner" of the job charged you a commission.... ${ }^{41}$

Sometimes I went to clean some big offices instead of my cousin... We were very similar, and her boss didn't say anything... ${ }^{42}$

To avoid controls migrants and employers develop specific strategies, which depend on the type of work. An important aspect, in all cases, is to try to pass unnoticed, especially when working on exposed sites.

A lot of friends have been caught because they were working outside. You must always work inside because if you are working outside they can always ask you for your working permit. ${ }^{43}$

I noticed that Carlos was very relaxed doing his job. He had to clean the stairs of a residence building. Yet, when he had to clean the street door of the building, the letterboxes that were outside and sweep the entrance of the building, he was nervous, worked at double speed and continually checked around. He said that that is the most dangerous part of his job... That when he is inside, nobody can check him. ${ }^{44}$

Many migrants agreed on the fact that in Amsterdam it is customary that inspections arrive because someone calls the police. Therefore, it is always advisable to be as little eye-catching as possible.

Many times there were inspections when I was on the building site. I had to hide, go to the roof. They first enter and ask, if they don't see anything weird, nothing happens, but if they

\footnotetext{
${ }^{41}$ Interview with Juan (10NM).

${ }^{42}$ Interview with Luisa (29NW).

${ }^{43}$ Interview with Juan (10NM).

${ }^{44}$ Fieldwork note.
} 
see something suspicious, they call and more inspectors arrive. Many times, they come because there has been a complaint. Here [in the Netherlands] there are many complaints. A group of friends of mine, they were Brazilian, they were working on a building site in the street and they were listening to music that the people here do not listen to. Or examples of Ecuadorians listening to $s a l s a$ or bachata... Then, they say: these are latino... For instance, when I work outside, on the street, for example painting, I always listen to a Dutch radio. If you want to listen to your music, use headphones and that's it. I always say to the new people, don't talk too loudly, don't sing... because here the people listen... I you are showy, to fail! But if you learn to be discreet, there's no problem. ${ }^{45}$

You know, you have to be careful. When you work illegally in construction, sometimes the owner of another company or even workers may report on you. They don't like us, because we steal their work and often do the job for lower prices. Two friends of mine were deported because they had been painting a house. Suddenly, the police came... A cousin of mine was able to escape because he jumped down from the window. He said that he is sure that the guys working in the next house called the police... ${ }^{46}$

In restaurants and hotels, the owners always told the migrants where to hide in case of a labour inspection or gave them other instructions so as not to raise suspicions. In certain cases, they had a way to alert the workers back in the kitchen or in the corridors, about the arrival of inspectors, so that they had enough time to hide.

In that hotel they told me not to wear the uniform, in case of a labour control I had to enter one room and pretend to be one of the guests. They also told me not to bring the bucket with the water or the trolley with the cleaning products into the rooms... ${ }^{47}$

When I worked in that restaurant there were three inspections. They always turned on a light and I knew that I had to hide in the container of the dirty sheets... Once I had to stay there for 2 hours, I almost choked. I thought they had forgotten about me... ${ }^{48}$

We knew what to do in case of inspections. In those years [before 2003] it was very unusual... but once we had an inspection. A Moroccan who was the oldest worker took me by the hand and we climbed from the stairs up to the roof. He told me to be careful because up there it was all greasy since it was where the extractors were released... After a while we heard something like a little bell, it was the cook beating with a knife on the metal... It meant the inspectors had gone... I didn't even see the guys of the inspection, their faces, what they looked like, how many they were. That was the only time, because before there were few inspections... ${ }^{49}$

\footnotetext{
${ }^{45}$ Interview with José (23NM).

${ }^{46}$ Interview with Pablo (16NM).

${ }^{47}$ Interview with Lola (5NW).

${ }^{48}$ Interview with Laura (24NW).

${ }^{49}$ Interview with Marta (7NW).
} 


\subsubsection{Work in Madrid}

\section{Sectors}

Two important elements emerged from the fieldwork regarding the working sectors of the Ecuadorian irregular migrants in Madrid.

On the one hand, a drastic difference was noticeable between the years that preceded the economic crisis which started in 2008 and the years afterwards. The first phase was characterized by the abundance of opportunities in a variety of sectors; the second phase by a general and drastic reduction of such opportunities and the virtual disappearance of entire sectors.

On the other hand, the sectorial division between men and women, present also in the Dutch case, appeared significantly more marked in Madrid.

The combination of these two factors generated four slightly different labourmarket and working opportunities for irregular migrants in Madrid: A. Men precrisis; B. Women pre-crisis; C. Men during the crisis; D. Women during the crisis.

Men in the pre-crisis phase were mainly employed in the construction sector. Among the 18 interviewed migrants, 14 had work at least temporarily in this sector. The other documented occupation sectors included: restaurants, industry, storage, transportation, and courier companies.

Women in the pre-crisis phase were employed in a variety of sectors with a certain prevalence of private-house cleaning and care work both for children and the elderly. Among the 12 interviewed migrants, 9 had worked mainly in private houses, 4 cleaning, 2 providing care to children and 4 providing care work for the elderly. The other documented occupation sectors included: restaurants, hotels, and professional cleaning.

While the effects of the crisis affected the whole labour market and, hence, also native workers and regular migrants, they were particularly tough for irregular migrants. As a matter of fact, the deterioration of the labour market conditions coincided with a restrictive turn on the part of the authorities. The combined effect was that the number of available positions fell and that for those positions many regular migrants were available.

The changed scenario especially affected men. The most important sector where they had found opportunities, e.g. the construction sector, literally collapsed.

After one week that I had been here, a friend of mine took me with him to the building site. The boss said: perfect, you can start right away. After that, I always worked in construction. I had to adapt, to learn all the names, because in Ecuador we call the tools with other names... My boss helped me to get the papers... The first year without a contract I earned 900 euro, then when I got the papers I started earning 1200 euro. It was very good. One day, in 2009, the owner of the company came and said to us: that's it. There is no more work. He closed the company and that was the end... Now there is nothing... for 2 years I have been doing little things to survive. ${ }^{50}$

${ }^{50}$ Interview with Pablo (3SM). 
I worked for more than 9 years in construction... At the beginning without papers and then with papers. I can tell you... That was crazy... we built, built, built... that seemed unstoppable... But we knew it could not last forever... we were building entire cities but there were no people... One day the company simply shut down and we were fired... From that moment on, it has been very difficult... ${ }^{51}$

For those who were still in an irregular administrative situation or who lost the papers, it became increasingly difficult to find opportunities to work. Among the interviewed, few had been able to keep their previous jobs in restaurants and in transportation; others started to find jobs in a sector that until that moment had been exclusively for women, e.g. house cleaning and care, while others relied on small occupations such as painting, gardening, electricity, etc.

I worked in that discotheque for more than five years... I had to clean and prepare everything for the next day... In 2007, the things started to go badly... Two of my colleagues were fired... My boss was very nice to me and he said that I could stay for some time. In 2008 , they fired my boss and me... Luckily, I had unemployment benefit for more than one year... Now I basically have not worked for 3 years ... I mean, sometimes a friend calls me for 1 month or little things... I am thinking of going back to Ecuador... ${ }^{52}$

Now with the economic crisis, for me it has become very difficult to find a job... Occasionally I find a couple of rooms to paint, a garden to look after or other small jobs like that [the term used is "chapuza" that literally means: 'work of little importance']. The reality is that now my wife is the one who is the bread winner...

When I could not renew the papers I didn't know what to do... There were no jobs for those with papers, imagine for me in that situation. I asked a friend of mine, who had been working for years with families, to help me. She introduced me to a woman she knew because she had worked at her house taking care of her father. They gave me an opportunity... I started working there... Thank god they didn't say anything about the papers... I think I was lucky, without my friend I would still be on the street. ${ }^{53}$

Right now my husband is in a worse situation than me... At least I have the chance to find hours or something [she means cleaning] in houses. He worked in construction for years, but now he has been unemployed for two years unemployed... Now it is a lot more difficult for men than for women. ${ }^{54}$

The situation was totally different... I know it because I was illegal at the beginning and I am illegal now. In the first years, I am talking about 2000, 2001, 2002, 2003... you just went to the square... There were queues of people waiting... all Ecuadorians... A car came and a man said: do you know how to pull cables? Yes! Jump in! It was super easy, then they knew you and they started calling every day... I worked in construction for years, I got papers, I earned money, I paid my debt back in Ecuador... When I could not renew my papers it was a cold shower... And so now I am illegal again. And now it is not like before... Imagine, my friends with papers are going back to Ecuador... Where do I find a job? ?5 $^{55}$

\footnotetext{
${ }^{51}$ Interview with Fernando (26SM).

${ }^{52}$ Interview with Walter (16SM).

${ }^{53}$ Interview with Luis (30SM).

${ }^{54}$ Interview with Patricia (1SW).

${ }^{55}$ Interview with Xavier (13SM).
} 
For women the situation has got worse as well. Yet, the cleaning and care sector seemed to be still offering opportunities.

Until recently I was working with a cleaning company... The owner was helping me with the papers... I was there for two years. Two years ago, though, he said to me: 'you had better not work until you have papers'. The people working there were legal, but they hired me because my cousins told him about me. He agreed to hire me... But since things have become more difficult, he told me to stay at home. Now, I have been unemployed again for 4 months. It is difficult because everyone asks you for papers... For one hour or two that you want to work they ask you for papers... ${ }^{56}$

Now it is has become very difficult. You have to have papers and you have to have references. For working with children or with the elderly, they ask you for references or the contact of someone that you have worked with. Before you simply went to a church and they gave you two or three telephone numbers of people looking for help at home. But now I have been to many churches to ask for work, since it is summer and there are a lot of people looking for someone who looks after the kids... But now everything is with papers... ${ }^{57}$

Because now that the government said they were going to fine those who employ without papers, the people do not risk anymore. There is an association that helps migrants where they have a job board. You go and every job is with papers, with papers, with papers... I have been there and they say: whoever does not have papers, please leave, because all the offers are for people with papers... There is another association in Arturo Soria [an area of Madrid]. There is a girl there that helps people to find jobs, she is there every Tuesday and Wednesday. There is always a queue of women waiting. She comes out and says: 'Girls, there are opportunities for those with papers, those without must leave'...58

\section{Conditions}

In the years before the economic crisis, finding a job in Madrid was very easy. The vast majority of the interviewed said that it took them only a few weeks to start working; that there were many opportunities in different sectors; that nobody asked for papers. Regarding the working conditions and the salaries, the picture appeared more controversial. While in some sectors, such as construction, industry, transport, migrants usually had good salaries, relative stability and the possibility to regularize; in others, such as restaurants, private houses and stores, the situation was more variable.

My boss was very nice, he really helped me a lot. I never felt exploited because I did not have papers. I knew how much those who were legal earned and it was the same as me... It was him who told me about the papers. His secretary did all the work, I had only to go and get them. ${ }^{59}$

\footnotetext{
${ }^{56}$ Interview with Patricia (1SM).

${ }^{57}$ Interview with Romina (8SW).

${ }^{58}$ Interview with Nuria (27SW).

${ }^{59}$ Interview with Daniel (7SM).
} 
I don't know how many people "made the papers" thanks to my company... They had many buildings... We worked a lot... I would not say it was easy... But you know, if you wanted, you could earn a lot, do extra hours, and everything. They helped us with the contract when there was the regularization... ${ }^{60}$

There was a lot of work! A lot! I worked all day, but I made a lot of money. Imagine, I was able to send to Ecuador 800 euros per month. That in Ecuador was a fortune... I bought two houses, one for me and the other to rent...61

In general, when the labour relations were more "personal", the possibility for underpayment, exploitation or delays in the papers was more recurrent. In particular, the women who worked as domestic help in private houses were those who had a higher degree of bad experiences.

In that house I worked from 7 in the morning to 10 at night when the kids went to bed... I had to do everything... Cleaning, cooking, ironing... everything. They gave me 450 euro... plus the room, but for all that work it was nothing... ${ }^{62}$

What really upset me was that they did not help me with the papers. I did not know how to do them very well... And the woman said to me all the time: don't worry I will take care of them, I will take care of them... I stayed there for three years and they never did anything. All my friends were settling their situation... I don't' know why they didn't want to help me... maybe they didn't want to pay me more... ${ }^{63}$

The owner of the restaurant was Ecuadorian... I can tell you... never work with the people of your country... They are the worst... I don't understand... Maybe it is because they come from the same place and now they feel superior... This guy made me work like crazy, every month he said to me: right now I only have this... Next week I'll give you the rest... bla, bla, bla... I left after 4 months... These people think that because you don't have papers you don't have dignity... ${ }^{64}$

Since the beginning of the economic crisis, the working conditions for irregular migrants have severely changed. On the one hand, the opportunities have fallen in every sector; on the other, the reduced opportunities have generated phenomena of downward competition.

Until a few years ago, one used to work and send money to Ecuador. There were many who took advantage of their opportunities and made money. There are others who did not. But now, we are only surviving. Today there is no chance to really progress. ${ }^{65}$

The problem is that the people are desperate to work. So, if you used to get 10 for one hour... now there are people who say $9,8,7 !^{66}$

\footnotetext{
${ }^{60}$ Interview with Victor (9SM).

${ }^{61}$ Interview with Alberto (23SM).

${ }^{62}$ Interview with Lucy (15SW).

${ }^{63}$ Interview with Marta (18SW).

${ }^{64}$ Interview with Hernán (24SM)

${ }^{65}$ Interview with Patricia (1SW).

${ }^{66}$ Interview with Luis (30SM).
} 
Have you noticed how many flyers you find on car windows? How many flyers on the letter boxes? Painting, plumbing, gardening, removal, everything... These are people trying to do whatever they can. Every day, I go and post my little flyers... How many people call? You know, I think this is the right moment to leave... ${ }^{67}$

\section{Controls and Strategies}

Also regarding the labour controls and the strategies developed to avoid them, the situation in Madrid displayed two very different phases.

Until the mid-2000s before the start of the economic crisis, migrants' descriptions reveal a very relaxed situation. The vast majority of these migrants never experienced a control on a work site and the employers were not worried about hiring people with an irregular status.

"There was no problem... You know, everyone was illegal... so you just went and you started working. I think they knew that nobody was going to check, because otherwise they would have been more worried.... ${ }^{68}$

In the construction? Never... never a single control... ${ }^{69}$

In the restaurant where I worked for more than 8 years, we never had a control... ${ }^{70}$

In all sectors there was work under the table..., in all sectors: painting, plumbing, construction, transport... And they could not check... I think it is too difficult. I don't know if they don't want to or they can't. For instance, I have always worked in the transport and removal sectors. Until recently, there were no checks at all... They should give fines to those you contract the service with... But they try to catch whoever is doing the work... and that is very difficult. How can you prove that they are working, that it is not a private thing... ${ }^{71}$

Working in houses, the control is impossible... It is the safest work... I never heard of anyone being checked or anything. Even now that they say controls are tougher, it is impossible. It is more dangerous because when you work in houses you have to move around the city, with the metro, with buses... That could be dangerous. ${ }^{72}$

From the mid-2000s on, and especially in certain sectors, a gradual increase of controls was recorded. The employers, who until that moment had been basically unconcerned, started to ask more frequently for papers or to develop strategies to avoid possible controls. Accordingly, also irregular migrants had to develop their own strategies in order to get hired.

\footnotetext{
${ }^{67}$ Interview with Fernando (26SM).

${ }^{68}$ Interview with Jesus (20SM).

${ }^{69}$ Interview with Alberto (23SM).

${ }^{70}$ Interview with Marcelo (6SM).

${ }^{71}$ Interview with Carlos (24SM).

${ }^{72}$ Interview with Lorena (27SW).
} 
They kept hiring irregular migrants. It became only a little more difficult. When I finally regularized... My name is Xavier Ramirez, we went to the working site and there were three Xavier Ramirez... My boss said to me: don't work there... I asked: why? He said: because there are two others with your name. I said: but you pay me the day? Yes! Since he had my documentation he could do that... I went back home but he had to pay me the day. Why? Because he had my papers. Before, I could not say anything because it was me who was the one working with the name of another... But now...

When controls increased, a lot of people made money acting as intermediaries. There were Ecuadorians and Peruvians who really made lots of money. They had contacts with the construction companies, they provided the workers, but for every guy with papers they send three or four workers... They were paid 10 euros and they gave 3 to the worker and kept the rest for themselves. ${ }^{73}$

\subsubsection{Comparison}

The work experience of Ecuadorian irregular migrants in Amsterdam and Madrid has presented a number of differences.

In both cities, during the considered years, migrants experienced important changes in their working opportunities.

In Amsterdam, it was possible to recognize two very distinct moments. The first, that lasted until the early 2000s, was characterized by the abundant availability of jobs in numerous sectors (construction, services, industry, cleaning). The second, from the mid-2000s on, was characterized by a progressive reduction of the available sectors. In particular, for irregular migrants it became increasingly difficult to find working opportunities in sectors other than private-house cleaning. As emerged from the interviews, this change was largely due to a restrictive turn on the part of the authorities. The increased inspections on the working sites and the higher fines in case of misconduct made it inconvenient for employers to hire irregular migrants. Moreover, the continuous arrival of large numbers of regular migrants from Eastern Europe offered them a valid alternative. Partly out of necessity, partly as an adaptive solution to the changed scenario, then, irregular migrants progressively moved to the private-house cleaning sector where they found a pretty stable, safe and rewarding labour niche.

Also in Madrid, it has been possible to distinguish two very different phases regarding irregular migrants' working opportunities. The first phase, which lasted until the end of the 2000s, was characterized by a great availability of working opportunities in many sectors. Although this was the case for both men and women, a rather marked sectorial division was registered. Men were mostly employed in the construction sector, women in private-house cleaning and the care sectors. The second phase, which started in 2008, with the beginning of the economic crisis, was characterized by a sharp reduction of the working opportunities that deeply affected

\footnotetext{
${ }^{73}$ Interview with Walter (16SM).
} 
all migrants. For irregular migrants, in particular, it became extremely difficult to find any occupation. The effects of the economic crisis on irregular employment were made even worse by a stricter control policy and the availability of workers with a regular status. Within this new changed scenario, the opportunities for irregular migrants became very limited. The construction sector, which had been the main attraction pole for men, simply collapsed. For women, the situation was slightly better, because the cleaning and care sectors were less affected by the economic downturn. Many migrants decided to move to another country or to go back to Ecuador. Those who remained tried to survive doing small jobs in the construction sector, transportation, or in services. For men, an option was to switch to the cleaning and care sector.

On the whole, while the double scenario is similar in both Amsterdam and Madrid, the underlying reasons for the dichotomy appear different, and likewise the consequences. In Amsterdam, the causes of changes experienced by Ecuadorian irregular migrants appear to be mainly political, in Madrid mainly economical. In Amsterdam, the increasing number of inspections in many economic sectors caused a sectorial shift on the part of the migrants. Since working in sectors such as construction, services and industry became increasingly difficult and risky, irregular migrants moved to the private-house cleaning sector. In Madrid, the effects of the economic downturn caused a general reduction of the working opportunities. For irregular migrants, it became very difficult to find a job in any sector. The reason in this case, was not, or not principally, that there were more controls, but simply that there was no work at all. Those migrants who had been able to regularize their status and who were also unable to find any employment have confirmed this impression.

Regarding the working opportunities for irregular migrants, two further differences can by underlined. Firstly, in the first phase, Amsterdam displayed a more even distribution of irregular migrants in different sectors (construction, services, industry, cleaning in private houses) and then, in the second phase, a concentration in one (cleaning in private houses). Madrid, instead, displayed a more marked concentration in some sectors (construction, cleaning and care) in the first phase and, in the second phase, a concentration in two (cleaning and care) but with scarce opportunities even there. Secondly, the cases revealed a different situation concerning gender distribution. While in both cases a certain sectorial difference emerged, in the case of Madrid this was much more marked.

An interesting facet regarding the topic under discussion concerns the care sector and, in particular, the care service for the elderly. While this sector has had a crucial role in Madrid, employing a vast number of irregular migrants and especially women, in Amsterdam employment in this sector has been completely absent. As pointed out by many migrants, in the Netherlands, the government offers a number of subsidized services to the elderly so that no working opportunities "under the table" are available in the sector.

Finally, also regarding the working conditions, the two cases have shown a differentiated picture. In Amsterdam, notwithstanding the necessary sectorial shifts, the working conditions for irregular migrants have generally and steadily been valued as positive. The large majority of the interviewed migrants told stories of 
relative success. They were treated well, were able to save money and to fulfil their economic expectations. In Madrid a distinction must be made. The interviewed migrants clearly distinguished in their stories between the pre-crisis and the crisis period. The first was generally characterized, although with a slightly higher number of exceptions, by a great availability of opportunities, good working conditions and economic success; the second, by very limited working opportunities, unstable and underpaid jobs.

\subsection{Internal Controls}

In this section, our analysis will be cantered on the experience of internal controls that Ecuadorian irregular migrants had in Amsterdam and Madrid. In particular, two aspects will be discussed: A. the experience of police (or other authorities) controls that migrants had in their daily lives; B. the actual fear that migrants had of being deported migrants.

\subsubsection{Internal Controls in Amsterdam}

All the interviewed migrants agreed on the fact that in Amsterdam there are no police raids or other authority controls specifically aimed at apprehending irregular migrants. However, they also agree on the fact that every aspect of everyday life, for instance, riding a bicycle, walking on the street, taking a bus, is severely regulated and closely controlled. A small slip during one of these activities can lead to an identity check and, therefore, for an irregular migrant to possible detention and expulsion. Going out at night to clubs, bars and discotheques can also be risky because in these places there can be controls when there are fights, selling of drugs, etc.

No, no... in this country there are no controls in the streets... I mean, there are controls in the labour sites, as for all workers, but not for the papers. Then if there is something irregular, they can ask you for your papers, but they never come for the papers... Here in the Netherlands, only if there is a complaint or if you made a slip, can they check you... Otherwise no... they let you live in peace... Those who have been caught, it is because they were in a nightclub, they had been drinking too much and they started a fight outside. Others, pitifully, were caught with the bicycles... We had never taken a lesson on how to ride a bicycle... like those for driving a car... This is a bicycle country, everyone moves with a bike. If you make a mistake and you are unlucky, a policeman stops you... Many of us have fallen for a red light, or for other little things... Those little things betray you... ${ }^{74}$

Here you can do whatever you want, unless you break the law... You can go to a nightclub, you can go to a park, you can get together with friends wherever you want without

\footnotetext{
${ }^{74}$ Interview with Maria (6NW).
} 
problems... It is not like in other countries that they look at your face, they see a stranger and they ask for your papers... No. This is one of the safest countries in that regard. There is no such thing as them checking you, just in case... They say that in other countries you are walking in the street and they ask you for the papers... There were controls here, a couple of times, but they were looking for guns. They announce these controls, they say: next week there will be controls for guns. They stop you in the metro, check your bag and that's it. They go after guns, they don't go after illegal people. ${ }^{75}$

I know that they know about us... The Dutch know about all the migrants, legal and illegal... Here everything is controlled... You think: I am hidden, they cannot see me... But I think that the Dutch are very smart and that here everything is checked. They know how many migrants are here... They know but they don't do anything... they wait until you fall... and in that moment... For instance if you walk in the street and you cross a red light, the police come and plin!! They get you. Or if you do anything wrong, or make a mistake, any mistake... they can get you and send you to your country. You always need to go around with your eyes wide open. ${ }^{76}$

Irregular migrants in Amsterdam have generally conducted normal lives as regards their free time or their movements around the city. In this sense, no particular feelings of threat or pressure on the part of the authorities was described. As pointed out by many, the important thing in the Netherlands is to respect the law, to avoid committing not only crimes but also "small faults" such as crossing a red light or having an expired ticket on the bus.

I've done everything... football, shopping, nightclubs... I have never felt inhibited... Of course, if you don't do illegal things... If you start a fight also if you are legal, you will have a problem... Imagine if you are illegal. Then, there is also a matter of luck... If you are in the wrong neighbourhood, at the wrong moment, it can happen that there is a raid for drugs and you are checked... But that is very unlikely...

"If you compare how the police work here and in Spain, it is very different. Here in the Netherlands the police are very tolerant. In Spain it is unbelievable... If you look like a latino, the police ask you for the papers. If you don't have them... to the jail... I travelled to Madrid once, to try to regularize my status there... The lawyer that was helping me said to me: I will give you a piece of paper sating that you are in the process of getting your papers... it is not legal, but if they stop you it helps. I left his office and took the metro. At the exit, in the underpass, the police stopped me: papers!! I gave them the paper I had just received... They said: ok! Pufff... I could not believe it... Then, I continued... That same day, in another metro station, another check... I said to myself: I have to go away right now. You know... here it is very rare that they stop you... The police do not run after illegal migrants. Unless you get into trouble, the police are calm... In Spain, in contrast, with or without problems, the police ask for papers... I have been here for 13 years, they have asked me for the papers 2 times... In Spain two times in one day... ${ }^{77}$

Here you need to follow the rules, you need to become responsible, you need to become organized. The migrant, the illegal person, cannot go every weekend to the nightclub until the morning... You know, in those places, legal or not legal, the police can ask you for your

\footnotetext{
${ }^{75}$ Interview with Juan (10NM).

${ }^{76}$ Interview with Lurdes (25NW).

${ }^{77}$ Interview with Mauricio (18NM).
} 
documentation... You have to be careful... Especially if you have a family... Look, if they get you, you will be back in Ecuador! Period! What will your wife do? What will your children do? So, what do you prefer? To make a sacrifice for your family or for your friends? For your family! ${ }^{78}$

Regarding the perception of the risk of being deported, the experience of the Ecuadorian migrants in Amsterdam has revealed an increasingly severe scenario. While expulsion has always been a concrete risk for irregular migrants in the Netherlands, since the early 2000s it has become almost a certainty for an irregular migrant who is caught.

There was a change around 1999 or $2000 \ldots$ Before that, even if they caught you, it was rare that they deported you... But, after that, they started deporting everyone... We were scared, you heard about this and that... Many people who were deported before 2003 were able to come back a week later... In Ecuador, you simply ask for a new passport... They had a different number each time... So, there was no problem... But after 2003, they started asking for the visa... If they sent you back, you could not return. ${ }^{79}$

Here there are no controls in the streets. Absolutely none! And I agree, there should not be... If they do that... we will be going back to the second world war... to Hitler... He made that kind of controls on the people... I think that this country suffered a lot due to that situation and it is because of that, that today they care a lot about human rights... What I don't like here is that they deport you for things that are not... not really important. They take as an excuse for instance, if you use the tram without a ticket, or if you go by bike with a broken light... They get you and they deport you. They need to justify the deportation... they need to respect the law... If you are robbing the state, they have a good reason: a migrant cannot rob the state! So they find an excuse and they deport you. ${ }^{80}$

Controls have become more intense each day. Every year they change the laws because they don't want people in this country anymore. It is getting harder all the time... I think they are angry because the migrants abused everything they gave them, especially the Turks and the Moroccans... It happened, for instance, that they were not working here but since they had social benefits, they could maintain the children they had back in their countries... I think that is what offended them... so now they are doing everything to eliminate migration, to make the life of the migrant impossible... especially that of the illegal migrant... You cannot study, you cannot get your qualifications, you cannot go to the hospital, etc. That type of thing... ${ }^{81}$

If they get you and are able to know who you are, they kick you to Ecuador $100 \% \ldots$ There is no way they will let you go now... Two nephews of mine have been deported... A friend of mine too... You know... It is very tough... So, you should not carry your documentation... If they catch you, you have to give the name of a legal person... ${ }^{82}$

\footnotetext{
${ }^{78}$ Interview with Pablo (29NM).

${ }^{79}$ Interview with Lorena (26NW).

${ }^{80}$ Interview with Gabriela (27NW).

${ }^{81}$ Interview with Javier (23NW).

${ }^{82}$ Interview with Mauricio (8NM).
} 


\subsubsection{Internal Controls in Madrid}

The experience of internal controls by the Ecuadorian irregular migrants in Madrid can be clearly differentiated into two phases.

While random identity checks and controls in the streets have always been a possibility, until the second half of the 2000s, these were very limited, unsystematic and largely inconsequential. A migrant could be stopped, asked for papers, even taken to the police station, yet this was very rare and usually did not have major consequences.

I was always outside... nothing happened... When I was illegal, the police stopped me on two occasions... The first time I was waiting for the bus... A policeman came and asked me for papers... I had only a photocopy of my passport... I was scared, but nothing happened... He looked at the picture, looked at me... and said: it's ok! Don't get into trouble... And he left... The other time was the same... ${ }^{83}$

I did not have a residence permit for more than 4 years... but I was not afraid I have to say... You know, the first months that I was here, I was worried but then I realized that there was no problem... There were no controls, there was nothing... I mean, probably there were controls here and there, just to take a picture and say that they were controlling, but c'mon... They all knew where we were. You just had to go to Tetuán or to Casa de Campo [a neighbourhood and a park where Ecuadorian migrants used to meet] and you could meet the whole of Quito [the Ecuadorian capital] playing football... If they had wanted, they could have sent 200 buses, got the people on a plane and sent them home... ${ }^{84}$

Since the beginning of the economic crisis in 2008 and, in particular, after the change of government in 2011, a marked change has taken place. Controls in the streets, metro stations and in gathering places, such as, parks, bars and discotheques became much more common, although intermittent. The migrant spoke about "spells of controls": particular months or weeks in which the controls increased.

This government that has entered now is always complaining about the migrants... the migrants, the migrants... The other, instead, Zapatero, I think he was in favour of the migrants, but this, this one hates us... You can see by the controls in the streets... Now the people without papers are afraid... Now you don't go out even to look for a job... ${ }^{85}$

One day I was in the metro... I was listening to the headphones... Two guys approached me... I thought they were going to sell me something... Then they took out their badge... They were policeman in plain clothes... They said: papers! Luckily it was all right... I had my papers... ${ }^{86}$

A couple of months ago, there were many controls... it goes in spells. In Metro Plaza de Castilla [the name of a metro station], there were those paisanos [policemen in plain clothes] as they call them. There were many of them, checking for papers. And also in Metro Usera... I always go there, because one of my cousins lives there... And I saw that

\footnotetext{
${ }^{83}$ Interview with Hernán (24SM).

${ }^{84}$ Interview with Daniel (7SM).

${ }^{85}$ Interview with Patricia (1SW).

${ }^{86}$ Interview with Lucy (15SW).
} 
they were also stopping women... they were taking them away... I could not believe it... Because, before, they used to stop only men, but now also women... ${ }^{87}$

Now there are a lot more controls. On two occasions they took me to the police station... In the two cases we were playing football with some friends... And you know, after the football, we always buy some litronas [beers]. After a while, the police came and started checking our papers... I had left my wallet at home... So they took me to the police station... Luckily that was when I still had the residence permit... But they kept me there from Friday to Monday... only because I did not have the documents with me... Right now they always come to check us... to the parks, to the little squares... when they see a group of us, they come and check our documentation. Also in the metro, there they are often in plain clothes. ${ }^{88}$

Luckily I got the papers in 2008 because, after that, they started with the raids... In every corner, in every metro station they could stop you. We were paranoid... I think it was in relation to the crisis... It was in that moment that the pressure against the migrants started... And especially against the migrant without documents. What they were trying to do was to scare the people so that they wouldn't come anymore.

When the raids started, there were latino radio stations that alerted the places where the police were... They alerted the illegal migrant... Be careful in that station, they are checking for documents there... It was the people who called to say where the controls were...

Also regarding the perception of the risk of being deported, the Ecuadorian migrants in Madrid have distinguished two phases. Until the beginning of the economic crisis, it was very unlikely for an irregular migrant to be deported. Most of the interviewed migrants agreed that it was very infrequent that you heard that someone had been sent back to Ecuador. After 2008, this situation slightly changed. As the controls increased, also the possibility to be deported increased. Yet, if in this second phase, those who were still in an irregular situation started to be more worried about a possible deportation, all the interviewed migrants agreed on the fact that, in order to be deported, it was generally not enough to simply not possess the residence permit.

Here in Spain it is not that they get you without papers and they deport you. No! You need to have a criminal record... You need to have been involved in something like fights, thefts, vandalism... Otherwise it is very difficult... They can even take you to jail or the CIEs [administrative detention centres] but they let you go after a while...

For them to take you to the CIE, you need to have done something, to have been involved in some trouble. A change took place with the beginning of the economic crisis. From that moment on, they started to check and deport the people. I had been stopped before, but, I swear, it was as if they checked you only to check you... The second time, I think it was two years ago [2011], a policeman stopped me. You could see that it was not like before. Now, they stopped the people and sent those without papers away. Now they were checking in order to deport. ${ }^{89}$

\footnotetext{
${ }^{87}$ Interview with Pilar (6SW).

${ }^{88}$ Interview with Pablo (4SM).

${ }^{89}$ Interview with Juan (10SM).
} 
I lost the papers in 2008, 5 years ago... It was because of a fight I had had with a policeman. You know in this country there is a lot of racism... They never check the Spanish kids... they go to the same park or to other parks... they drink, do drugs, pee on the street... everything. But if the police arrive, they come directly to us... They see a group of latinos and they come. They treat us very badly, they put us against the wall to check our pockets. So I made the mistake of reacting... The policeman pushed me, I pushed him, he gave me a punch, I did the same... After two seconds I had all the policemen over me... I had a trial and of course I lost, there were 15 policemen accusing me... In that moment I lost the papers... Since that moment it has been hell... I have been to the CIEs 4 or 5 times... Every time they stop me, they ask me for the papers. I end up in the CIE. They have not deported me because my father always sends a lawyer... If you don't' have a lawyer that acts within 5 hours and you have a criminal record like me, they put you on a plane... If you don't have a criminal record and you have someone who helps you, they don't send you". ${ }^{0}$

Here the police are very nice... If you do what you have to do, if you don't get into trouble they don't do anything to you. Here everybody is complaining about the police, but if you pay attention, those who complain are those who have done something. I don't fear the police... I always think that I am not a criminal, that I have nothing to be ashamed of. Many times they have asked for the papers. Many times. I tell them that I am in a process, that I am waiting and that everything is going to be all right. They always say to me: ok! Good luck! If you are serious and explain your situation, nothing happens. They deport the criminals, not those who are not doing anything. If they get you with drugs, drunk in a nightclub, in a fight, they put you on a plane... ${ }^{91}$

\subsubsection{Comparison}

The results that emerged from the fieldwork have revealed two different situations regarding internal controls in Amsterdam and Madrid.

In Amsterdam, there have not been ad-hoc controls on irregular migrants in the streets or in public places. Migrants, therefore, did not feel under direct threat and did not usually feel scared about moving around and carrying out their normal activities. However, the rigid checks regarding respect for the rules that regulate most social activities, such as, walking in the street, riding a bike, using public transportation, have been an indirect form of control. Irregular migrants know that a simple mistake, an administrative fault of any kind, can lead to an identity check, to administrative detention. For these reasons, these people are usually very alert to the situation around them at all times and very self-controlled in their public activities. Regarding the possibility of being deported, the impression gathered is that in Amsterdam this has become in the last decade a very realistic one among irregular migrants. In other words, most migrants seem to know that if they get caught, the most probable consequence is that they are going to be deported.

In Madrid, there has always been the possibility of ad-hoc controls on irregular migrants. Until the second half of the 2000s, though, these were very limited,

\footnotetext{
${ }^{90}$ Interview with (19SM).

${ }^{91}$ Interview with 20SM.
} 
unsystematic and largely without any consequences. Migrants, therefore, described a very relaxed situation and a negligible possibility to be deported. After the start of the economic crisis, this scenario changed. The controls on irregular migrants became more frequent and systematic. Every street, metro station or public place could be the place for a potential raid. These controls, however, were rather intermittent. They increased in particular months or weeks and diminished afterwards. While the fear of being deported certainly increased in the second phase, for the interviewed migrants, this possibility remains rather unlikely. As pointed out by many, in order to be actually deported, it is usually not enough to simply not possess a residence permit; the irregular migrant has to have a criminal record.

\subsection{Housing and Healthcare}

In this section, the experience of Ecuadorian irregular migrants in Amsterdam and Madrid regarding three important aspects of their daily lives, namely housing, healthcare and education for the children, will be analysed.

\subsubsection{Amsterdam}

\section{Housing}

Finding a house to live in and stay for a relatively stable period has been one of the most difficult tasks for irregular migrants in Amsterdam. All the interviewed migrants, with no exception, indicated housing as the biggest problem they had to deal with in Amsterdam. The difficulty was related to the general scarcity of houses and to the existence of a very controlled system of public houses. The main available option for irregular migrants was to sublet rooms or entire houses from people who get the houses from the public service. This option, however, was usually very unstable because this type of houses is greatly controlled by the authorities. If a control came, the migrants had to depart in that moment, many times leaving their belongings behind, or losing the money they had paid to get the house.

The house is the biggest problem here in Amsterdam. Imagine: there is no house for the Dutch, so what do you expect for irregular migrants? I have changed more than 10 houses in the last number of years... It is really bad. ${ }^{92}$

Here it is very difficult. If you don't have someone who knows you, it is very difficult to get a good house. You cannot go and say: I want a room or a house. They ask you for your residence permit. The other option is to sublet a room in a government house, but in that case you never know if a control may come. Those houses are very much controlled. They come

\footnotetext{
${ }^{92}$ Interview with Marta $(7 \mathrm{NW})$.
} 
to check if the owner is really living there or if he is subletting. That is very common here in Amsterdam, someone gets a house from the government, but they don't live there, they go to live with their girlfriend or boyfriend, and rent the house under the table... You are always scared in that situation... Unless the owner lives there as well, you'd better be careful... ${ }^{93}$

Every Ecuadorian here has struggled for the house... everyone. It is horrible, horrible! I have lived in 15 different places... I think the only district where I have not lived in is Amsterdam-Noord; otherwise I have lived everywhere. The problem is that the country is small and there are a lot of people. Even for the Dutch, it is difficult to get a house. They have to wait $7,8,15$ years in order to have a house [she means a public house]. The houses are very small and expensive. So, if you rent a house or a room, you have to pay the deposit, one month in advance and the first month. After one month they can tell you: Out!. And you cannot do anything. The money is lost! $!^{94}$

If you have money it is easier to find a house. Here, there are a lot of people who work as intermediaries. The risk of fraud is high. Once we lost 2,000 euro in 10 minutes. They tell you: today I have three clients that want this house. They know you are illegal... If you get the house, when they want, they can come and say: get out or I'll call the police... If you are lucky you can stay in the house for 2,3 years...95

The house is the most difficult thing here... I have been here for 13 years and I think I have changed 24 houses. That is because I have always found a house with people that have a government house and those are the people that are checked most by the police. So, every minute a control can arrive. We have been in a house for 3 months and out, three months and out! Sometimes you don't know what to do... With my husband we have slept in the park... Once, with my child, we had to sleep in a taxi. A guy from Suriname was very kind and he let us sleep in his taxi... The guy where we used to live let us the room for 600 euro... He rented the other room as well. He occupied the living room. I think for the whole house he had to pay 400 euro... Do you understand? He made a lot of money. For sure someone told the police he was subletting. We always had to leave the houses for this kind of situation... people who were living on public benefits or who had some kind of trouble. If a letter arrived that the control was coming, we had to leave. ${ }^{96}$

\section{Healthcare}

The access to healthcare for Ecuadorian irregular migrants in Amsterdam has been another problematic issue. If, until 1998, they had been able to freely access the public service, from that year on, the residence permit became a necessary requirement to be treated for free. As a matter of fact, no healthcare insurance could be stipulated without a valid residence permit and, without insurance, the people had to pay all medical assistance. For irregular migrants, consequently, the only option

\footnotetext{
${ }^{93}$ Interview with Marco (11NM).

${ }^{94}$ Interview with Gabriela (27NW).

${ }^{95}$ Interview with Pablo (28NM).

${ }^{96}$ Interview with Laura (24NW).
} 
in order to access the public medical assistance was to pay. Many migrants had medical problems, they all went to hospital and paid.

For more or less 10 years now, things have been very difficult. We were not 50 or 60 who went to the hospital... We were $500 \ldots$ Each time that you go to the hospital it costs at least 300-400 euros... So that was a debt that the government has. I think it was for that reason that they changed the law. Now you cannot buy a medical insurance, you need the residence permit. There is a fund that the hospitals can use in cases of emergency for us... [by "us" she means irregular migrants]. So now, what we have to do is to hope not to get ill, otherwise you have to go and pay the bill... Sofia, that friend of mine, broke her leg... I think she has 15,000 euro of debt with the hospital...97

We solved the healthcare issue by eating well, so that we don't get ill... If we get ill we use "home medicine"... The hospital is too expensive and since we have no medical insurance it is also a bit difficult... Once I broke my elbow... I went to the hospital and I needed x-rays and a head scanner, because I had fallen down the stairs the stairs. They thought I could have something in my head... It happened while I was working in a house. The woman said to me: are you ok? I am sorry!! She didn't say anything else... She didn't ask how much I had to pay in the hospital... When you don't have papers, you have no rights... So I went to the hospital... In the end, a social worker came and said to me: you have to pay, what do you want to do? She told me that I could pay in monthly instalments. For the whole thing it was 2800 euro. I had to pay, because there are others who don't pay, they use the fund that the hospital has for irregular migrants... The problem is that if you do not pay, the next time they don't see you. Now they have a file with my information. If I go again they know everything, even my form of payment... Now, for instance, I will have to go to give birth [Luisa is pregnant at the moment of the interview], I don't know how much I will have to pay... ${ }^{98}$

Some migrants have internalized this situation and act accordingly. Mauricio, for instance, has a very pragmatic understanding of the irregular migrants' relations with the state and the public services. If you have a residence permit, you can use the insurance system; if you do not have insurance, you have to save the money and be prepared to pay.

When you are illegal, you have the advantage that you earn more... If you work legally, you have to pay a lot of taxes; they take out 400 euro, 500 euro per month. But, if you think logically, when you get ill you don't have insurance, when you are old you will not have a pension. So the extra money you get now, you have to save it. You have to build your own insurance under the mattress...99

A number of alternative strategies have been elaborated to avoid the high costs of the public healthcare. Some migrants have been able to use the insurance number and the documents of other people. Others, in the case of small problems, have gone to the Red Cross, which provided a basic service for irregular migrants under the payment of 5 euro. Another option was to go to private "unofficial" doctors who worked under the table. Finally, an interesting case was that of Gabriela, who, to avoid the costs of giving birth in Amsterdam, decided to travel clandestinely to Spain.

\footnotetext{
${ }^{97}$ Interview with Maria (6NW).

${ }^{98}$ Interview with Luisa (29NW).

${ }^{99}$ Interview with Mauricio (18NM).
} 
Luckily I never had problem, so I didn't need to go to the hospital. I discovered how expensive it was when I had to give birth. One echography costs 200 euro... Here they don't give you anything, absolutely anything if you are illegal. Now I am legal and I pay insurance, so I can go whenever I want. But when I was illegal I could not. I mean, I could but I had to pay. You can go and give birth but it can cost 7,000 -9,000 euro. When you are a first-time-mother you often have complications... and the price rises. I had complications!! I thank the Lord I went to Spain to give birth, because here it would have been 10,000 euro. I would now have a debt... My mother used to live in Spain, she told me to come here to give birth. I decided to go. I have to say that they often say that people are racist in Spain, but I think that, regarding healthcare, they are very humanitarian. I went, I gave birth, they treated me, they cured me. I stayed in hospital for 5 days. Can you imagine how much that costs here? Moreover, here they treat you very badly... They kick you out of the hospital the same day... If you have a complication, you stay 5 hours, not like in Spain or Ecuador where you stay 5 days. ${ }^{100}$

\subsubsection{Madrid}

\section{Housing}

Finding a house in Madrid was a problem for an irregular migrant only in the very first years of the Ecuadorian migration. As pointed out by many of those who were part of the first wave of migrants, at the end of the 1990s, there were not many houses and it was not easy to find accommodation. In this early stage, the most common solution was to rent a room or even a bed in a room from people who were making money from this kind of business. The conditions were usually very bad and the prices relatively high.

When I had just arrived [1997] I didn't know anybody... I had a cousin who told me that there was a Peruvian woman renting rooms... I remember that I went to talk to her and she told me the price... I don't remember because it was in pesetas... I think it was something like 190 euro... The room was big... And so, I asked if the people who owned all the luggage that was in the room were coming to pick it up. She looked at me as if I was crazy... I thought the room was all for me... [laughs]. There were 8 of us in that room, can you believe that? ${ }^{101}$

At the beginning it was difficult. The Spaniards didn't want to rent you a house without the nomina [a working contract] and you could not have a contract without the papers... So the only option was to rent rooms... You know, in Ecuador there is a lot of space... we were not accustomed to renting rooms, to living with other people that you don't know... It was hard. ${ }^{102}$

A friend helped me when I first arrived... They had a small house, because he had already got papers... I had to sleep on the couch... the problem was that they rented the other couch to another women from Ecuador and they had a big dog... I was crazy! After one day I said: I cannot stay here... They helped me to find another place with a friend of theirs... it was

\footnotetext{
${ }^{100}$ Interview with Gabriela (27NW).

${ }^{101}$ Interview with Xavier (5SM).

${ }^{102}$ Interview with Hernán (24SW).
} 
on another couch... That was at the beginning... Then you start making contacts... knowing people and it becomes easier. The next place was an entire room for me in a house with other migrants... ${ }^{103}$

As the first migrants started to regularize their status and were able to rent entire houses, the renting market rapidly expanded. Already in the first years of the 2000s, the issue of the house had become a lot easier for irregular migrants. A great number of Ecuadorians, moreover, helped the newly arrived to rent from family or friends.

For me the house has not been a problem... When I arrived I stayed at my sisters', I think for 2 years... Then my boss told me he had a flat... You know... they were building entire neighbourhoods... For whom do you think they were building all those houses?? For the migrants who were arriving in hordes!! So I went to live in that house... My boss did not ask for papers, of course, he knew I did not have them, but then when I got them, he gave me a contract. And do you know what I did with the other room in the house? I started renting the other room to a friend of mine... ${ }^{104}$

In the first years the housing situation was not easy... I think it was because the Spaniards did not trust the Ecuadorians... Then I think they started to know us better, to see that we were good workers. As soon as I got the papers, I was able to rent this house. I have been living here for more than 11 years... The owners are very happy with us because we never missed a payment and we don't create problems. My house has been like the gate to Spain for the Ecuadorians... I have hosted all my family, friends, friends of friends... ${ }^{105}$

\section{Healthcare}

Healthcare has not been a problematic issue for Ecuadorian irregular migrants in Madrid. As established by the law, all the migrants registered on the municipal record, with no regard to their administrative status, were allowed to freely access the public healthcare system. All the interviewed migrants have confirmed the correct implementation of this provision; none of them has had any problem in accessing the service.

\subsubsection{Comparison}

The access to housing and healthcare for Ecuadorian irregular migrants in Amsterdam and Madrid has presented a number of important differences.

Regarding the first issue, the access to housing in Amsterdam has been generally much more difficult than it is in Madrid. This has been due to two main factors: A. the lower supply of housing opportunities; B. the existence of a strictly regulated and controlled system of public housing. The combination of these factors

\footnotetext{
${ }^{103}$ Interview with Lorena (25SW).

${ }^{104}$ Interview with (26SM).

${ }^{105}$ Interview with Leticia (11SW).
} 
determined a very precarious situation for irregular migrants' housing. The available options were generally unstable, expensive and at risk of frauds. In contrast, in Madrid, after a first moment in which the housing opportunities had been relatively scarce, the situation rapidly improved. As many Ecuadorians and migrants from other countries started to get their status regularized, they were able to rent entire houses or flats and sublet rooms to the newly arrived. This determined a quick expansion of the housing opportunities and, therefore, the availability of relatively cheap, stable and safe housing for the irregular migrants.

As far as the second issue is concerned, a similar situation has been found. In Amsterdam, access to healthcare has been much more problematic for irregular migrants than in Madrid. In this case, the determining factor was the different regulations regarding access to the public healthcare system. Whereas in Amsterdam, irregular migrants have been excluded from non-emergency care since 1998, in Madrid they could freely access the public system until 2012. Hence, while for irregular migrants in Madrid, the issue of healthcare was basically not a problem, in Amsterdam they had to find ways to overcome the existing limitations. The most common option, in case of serious medical problems, was to go to the public hospitals and pay the costs at market prices. For minor problems, there was the option of medical support offered by humanitarian associations or by private unofficial doctors.

\subsection{Irregular Migration Realities in Amsterdam and Madrid}

The first and most important conclusion stemming from the fieldwork realized in Amsterdam and Madrid, is that the experience of Ecuadorian irregular migrants in the two cities has been radically different. The diverse combination of possibilities, limitations, opportunities, resources, etc., present in the different spheres of social life in the two contexts determined a set of very different conditions for irregular migrants in order to develop their lives and fulfil their objectives. This result seems to confirm the hypothesis which emerged in the theoretical part of this study: the existence of different "irregular migration realities". While in legal terms, the lack of a residence permit generates, in principle, a similar condition, the "social translation" of this condition sharply differs, depending on where such translation takes place.

While this conclusion may seem rather obvious or predictable, the truth is that it is not. As extensively discussed in the first part of this work, one of the main limitations in the current understanding and study of irregular migration has been the tendency to treat it as an undifferentiated phenomenon. It was also saw, how this problem had both a theoretical and an empirical origin. On the one hand, irregular migration had been studied using unsophisticated theoretical tools; on the other hand, there has been a lack of comparative analysis of the 
phenomenon. If in the theoretical chapters it was tried to challenge this problem in analytical, logical terms, producing the hypothesis of differentiated, systemic contingent "irregular migration realities". Here it was tried to go to the field and discover if such hypothesis was realistic.

In the next chapter, an attempt to assess possible systemic relations between the structural characteristics of the two contexts, analysed in Chap. 6, and the irregular migration realties, which emerged from the fieldwork will be presented. Before that, then, in this final section, an effort to produce a general characterization of the irregular migration realties in Amsterdam and Madrid will be made.

Not only has the experience of Ecuadorian irregular migrants been different in Amsterdam and Madrid, but it has also gone through different phases within each of the two contexts during the considered period of time (1997-2013). This reveals how the irregular migration phenomenon differentiates across space but also across time.

In Table 7.1 it is possible to observe a summary of the main findings of the fieldwork.

The experience of Ecuadorian irregular migrants has offered many insights into the irregular migration realities in Amsterdam and Madrid. Let's see them in detail.

Table 7.1 Irregular lives Amsterdam and Madrid

\begin{tabular}{|c|c|c|c|}
\hline & & Amsterdam & Madrid \\
\hline \multirow[t]{3}{*}{$\begin{array}{l}\text { Legal trajectories } \\
\text { and regularization } \\
\text { channels }\end{array}$} & $\begin{array}{l}\text { Main } \\
\text { trajectories }\end{array}$ & $\begin{array}{l}\text { Never regular }(17 / 39) \\
\text { Regularized through } \\
\text { marriage or cohabitation } \\
\text { agreement }(11 / 30) \\
\text { Regularized under } \\
\text { exceptional circumstances } \\
(2 / 30)\end{array}$ & $\begin{array}{l}\text { Regularized using ad-hoc } \\
\text { channels }(21 / 30) \\
\text { Befallen irregularity }(6 / 30) \\
\text { Never regular }(3 / 30)\end{array}$ \\
\hline & Irreg. years & 12 years (average) & 5 years (average) \\
\hline & Channels & $\begin{array}{l}\text { Indirect: (1) marriage and } \\
\text { cohabitation agreements }\end{array}$ & $\begin{array}{l}\text { Direct: (1) extraordinary } \\
\text { regularization programs, (2) } \\
\text { through labour quotas; (3) } \\
\text { through rootedness }\end{array}$ \\
\hline \multicolumn{2}{|c|}{ Regularization strategies } & $\begin{array}{l}\text { Bogus marriage or } \\
\text { cohabitation agreement } \\
\text { with a Dutch citizen - } \\
\text { very difficult } \\
\text { Bogus marriage or } \\
\text { cohabitation agreement } \\
\text { with } \\
\text { a EU citizen - difficult }\end{array}$ & $\begin{array}{l}\text { False contracts to apply for } \\
\text { regularization } \\
\text { False police record to apply } \\
\text { for regularization }\end{array}$ \\
\hline
\end{tabular}


Table 7.1 (continued)

\begin{tabular}{|c|c|c|c|}
\hline & & Amsterdam & Madrid \\
\hline \multirow[t]{3}{*}{ Work } & Sectors & $\begin{array}{l}\text { Before mid2000s, men: } \\
\text { hotels, restaurant, } \\
\text { construction, port, and } \\
\text { industry } \\
\text { Before mid2000s, women: } \\
\text { hotels, restaurants, office } \\
\text { cleaning, private-house } \\
\text { cleaning } \\
\text { After mid2000s, men: } \\
\text { private-house cleaning } \\
\text { and construction } \\
\text { After mid2000s: women: } \\
\text { private house cleaning }\end{array}$ & $\begin{array}{l}\text { Before 2008, men: } \\
\text { construction, restaurants, } \\
\text { industry, storage, } \\
\text { transportation, and couriering } \\
\text { Before } 2008 \text {, women: } \\
\text { private-house cleaning, office } \\
\text { cleaning, care work with } \\
\text { children and the elderly. } \\
\text { After } 2008 \text {, men: "little jobs" } \\
\text { in construction, } \\
\text { transportation, care work } \\
\text { with the elderly } \\
\text { After } 2008 \text {, women: care } \\
\text { work with children and the } \\
\text { elderly, private-house } \\
\text { cleaning }\end{array}$ \\
\hline & Conditions & $\begin{array}{l}\text { Work availability: } \\
\text { Before mid2000s: high } \\
\text { After mid2000s: } \\
\text { medium } \\
\text { Working conditions: } \\
\text { generally medium to good } \\
\text { Wages: generally high }\end{array}$ & $\begin{array}{l}\text { Work availability: } \\
\text { Before 2008: very high } \\
\text { After 2008: very limited } \\
\text { Working conditions: } \\
\text { generally medium to good, } \\
\text { some cases of exploitation } \\
\text { Wages: } \\
\text { Before 2008: high in } \\
\text { certain sectors, medium in } \\
\text { others } \\
\text { After 2008: medium in } \\
\text { certain sectors, low in } \\
\text { others }\end{array}$ \\
\hline & Controls & $\begin{array}{l}\text { Before mid2000s: } \\
\text { medium } \\
\text { After mid2000s: high }\end{array}$ & $\begin{array}{l}\text { Before mid2000s: very low } \\
\text { After mid2000s: medium }\end{array}$ \\
\hline \multirow[t]{2}{*}{ Internal controls } & \begin{tabular}{|l|} 
Street \\
controls
\end{tabular} & $\begin{array}{l}\text { No street } a d-h o c \text { controls } \\
\text { for irregular migrants }\end{array}$ & $\begin{array}{l}\text { Before 2008: limited, } \\
\text { unsystematic, inconsequential } \\
\text { After 2008: in spells, } \\
\text { systematic, with } \\
\text { consequences }\end{array}$ \\
\hline & $\begin{array}{l}\text { Fear of } \\
\text { deportation }\end{array}$ & $\begin{array}{l}\text { Before 2000s: medium } \\
\text { Until mid2000s: high } \\
\text { After mid2000s: very high } \\
\text { Who can be deported? } \\
\text { Everyone }\end{array}$ & $\begin{array}{l}\text { Before mid2000s: very low } \\
\text { After mid 2000s: medium } \\
\text { Who can be deported? Those } \\
\text { who have a criminal record or } \\
\text { precedents }\end{array}$ \\
\hline \multicolumn{2}{|l|}{ Housing } & $\begin{array}{l}\text { Very difficult, unstable } \\
\text { and expensive }\end{array}$ & $\begin{array}{l}\text { Before 2000/2001: difficult } \\
\text { and expensive } \\
\text { After 2000/2002: } \\
\text { increasingly easy and } \\
\text { inexpensive }\end{array}$ \\
\hline \multicolumn{2}{|l|}{ Healthcare } & $\begin{array}{l}\text { Until 1998: free access to } \\
\text { healthcare } \\
\text { After 1998: access under } \\
\text { payment with the } \\
\text { exception of emergencies }\end{array}$ & $\begin{array}{l}\text { Until 2012: free access to } \\
\text { healthcare } \\
\text { After 2012: access under } \\
\text { payment (no cases in my } \\
\text { sample) }\end{array}$ \\
\hline
\end{tabular}




\subsubsection{Amsterdam}

In Amsterdam, the experience of Ecuadorian irregular migrants became increasingly difficult along the considered period of time. The policy changes adopted since the end of the 1990s, appear, in this sense, to have been effective in restraining the living opportunities of irregular migrants. This has influenced both the size and the conditions of the irregular migrant community. While numbers have never been big, it seems that the increasing restrictiveness has determined an effective disincentive on new arrivals.

Irregularity has appeared as a long term, hard to change condition for migrants in the Netherlands. The lack of ad-hoc regularization channels and the strict control over possible alternative regularization strategies, such as, marriage and cohabitation agreements, have made it very difficult for irregular migrants to obtain a residence permit. It was, then, normal to find migrants with more than 10 years of irregular residence in the Netherlands. Those few who were able to regularize, achieved this result after different attempts and after investing important quantities of money.

Regarding the experience of internal controls, the scenario has been contrasting. On the one hand, the absence of ad-hoc police controls of irregular migrants in the public spaces has generated among irregular migrants a feeling of relative tranquillity and sense of freedom. On the other hand, the strict control over the respect for the rules regulating many social activities, such as, work, house rental, car driving, bicycle riding, street circulation, public transportation use, as well as the strict application of the deportation policy, generated among migrants an ever present sense of vulnerability and a highly developed sense of alert and self-control.

The working opportunities and conditions for irregular migrants in Amsterdam, have been evidently affected by the restrictive turn adopted by the government since the end of the 1990s. The most evident result of this change has been the reduction of sectors where irregular migrants were able to find employment. In the last few years, private-house cleaning has been the niche where most migrants have found stable and remunerative opportunities. That being said, the economic success has been one of the most valued aspects of irregular migrants in the Netherlands. Notwithstanding the difficulties related to the language, the high levels of controls, the risk of deportation, and, in the last few years, the reduction of working opportunities, migrants were generally able to find jobs, to earn and save money and to send money back to Ecuador.

Regarding the access to vital resources, such as, housing and healthcare, the experience of irregular migrants in Amsterdam has been very problematic. As for housing, the particular characteristics of the Dutch housing market and, especially, the limited supply of opportunities and the strictly controlled system of public housing, has determined very precarious, unstable and expensive conditions for irregular migrants. Moreover, the combination of a low supply of and a high demand for houses has fostered cases of frauds and abuses. In the case of healthcare, the impossibility to freely access public healthcare since 1998, severely complicated the situ- 
ation for irregular migrants. The requirement to pay for the services in public hospitals, implied for migrants the search for alternatives, such as, the help of private doctors or humanitarian associations, the accumulation of debts and, in certain cases, the neglect or mistreatment of dangerous illnesses.

The combination of all these conditions has created an increasingly difficult environment for irregular migrants. As an adaptive solution, migrants have been obliged to develop sophisticated strategies to overcome limitations and barriers or to recur to the services and options offered by underground or even criminal organizations. While the possibilities to regularize have been very limited and many spheres of daily life quite problematic, the economic opportunities have been a sort of counterweight. Although the indirect police pressure is high and the risk of being deported is tangible, Ecuadorian irregular migrants have been quite effective in adapting to the environment and in developing reasonably serene and successful trajectories. Once they learn how to deal with the main problems and to behave in a discreet way, it is possible for them to conduct a parallel existence to that of the "regular" citizens. Paradoxically, in purely economic terms, their options may be even better. At least in the short, medium term, then, most migrants considered their experience as successful. The issue of the papers becomes truly critical for irregular migrants only when their children approach legally adult age and face the possibility of having to abandon their studies and start working with them.

\subsubsection{Madrid}

In Madrid, the experience of Ecuadorian irregular migrants went through two very different phases in the considered period of time: the first, between the end of the 1990s and 2008, and the second, afterwards. The first phase was characterized by the massive arrival of irregular migrants, the abundance of working opportunities and the possibility for the irregular migrants to easily regularize their status. A sharp reduction or even the inversion of the fluxes, the collapse of the job market and the reduction of the regularization opportunities characterized the second phase. Although a number of political reforms implemented by the authorities through the 2000s may have certainly effected the situation, the decisive factor in determining the change of scenario in 2008 was the start of a serious economic crisis in Spain.

Irregularity has appeared as a transitory condition for migrants in Spain. The existence of a number of ad-hoc regularization channels has made it easy for irregular migrants to obtain a residence permit. The crucial role of holding a working contract or a job offer in all the regularization schemes, however, made it a lot more difficult for irregular migrants to get a residence permit after 2008. 
Notwithstanding this, at least among Ecuadorians, it has been very difficult to find migrants with more than 5 years of irregular status.

Regarding the experience of internal controls, the scenario has been very different in the two described phases. While police controls on irregular migrants in the public spaces have always been carried out, until 2008 these were very limited, unsystematic and usually inconsequential. After 2008, this type of control was implemented in spells, but in a much more extensive, systematic and determined way. In connection with this development, the perception of the possibility of being deported, which until 2008 had been negligible, definitely increased. Yet, as underlined by most migrants, even during the apex of police raids and deportations in 2011 and 2012, the common perception was that in order to be expelled, it was necessary to have a criminal record or a recurrent story of detentions. As for other types of controls, such as those on the working sites, house rental and other social activities, although migrants have perceived a restrictive trend, especially in the second part of the 2000s, these controls have not been a reason for major concern. On the whole, then, it is possible to say that Ecuadorian irregular migrants in Madrid had a very serene and carefree experience of controls until the end of the 2000s. After that, the concern increased and, in particular, during certain periods, it created a concrete sense of vulnerability.

The working opportunities and conditions for irregular migrants in Madrid, have been evidently affected by the economic crisis which started in 2008. If, until then, both men and women had been able to find plenty of opportunities in a number of sectors, after that, especially for men, it became truly difficult to find an occupation. This dramatic change severely affected the economic situation of all migrants and particularly of those without a residence permit. The sharp increase in unemployment among the general population, made it very difficult for irregular migrants to get a job offer. The only sectors where they were still able to find relatively stable and remunerative jobs were private-house cleaning and the care sector. The assessment of the economic experience of Ecuadorian irregular migrants in Madrid can be considered as twofold. Until 2008, these irregular migrants were successful because they were able to work, earn and save money, and also send money back to Ecuador. After 2008, these people were unsuccessful and in most cases had to limit themselves to basically surviving.

Regarding access to vital resources, such as housing and healthcare, the experience of irregular migrants in Madrid has been relatively easy. As for housing, the rapid expansion of the market and the low level of controls in the sector meant good, inexpensive and stable opportunities for these migrants. As regards healthcare, the possibility for irregular migrants to freely access the public healthcare system generated a very convenient and unproblematic situation. 
The picture that emerges from this overview once again is twofold. Ecuadorian irregular migrants in Madrid experienced two very different phases. Although each phase was characterized by a number of specificities, the most decisive, discerning element appears to have been the difference in the working opportunities. After 2008 , the deterioration of the economy severely affected all the population. However, the effects of the lack of work were particularly relevant for irregular migrants since this not only affected their economy, but also their possibility to regularize or maintain a temporary residence permit.

Open Access This chapter is licensed under the terms of the Creative Commons Attribution 4.0 International License (http://creativecommons.org/licenses/by/4.0/), which permits use, sharing, adaptation, distribution and reproduction in any medium or format, as long as you give appropriate credit to the original author(s) and the source, provide a link to the Creative Commons licence and indicate if changes were made.

The images or other third party material in this chapter are included in the chapter's Creative Commons licence, unless indicated otherwise in a credit line to the material. If material is not included in the chapter's Creative Commons licence and your intended use is not permitted by statutory regulation or exceeds the permitted use, you will need to obtain permission directly from the copyright holder.

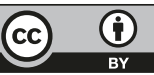

